\title{
The lichens and allied fungi of the southern part of the Kenozersky National Park (Arkhangelsk Region, NW Russia)
}

\author{
Aleksey V. Pchelkin ${ }^{1}$, Viktoria N. Tarasova ${ }^{2}$, Andrei A. Valekzhanin ${ }^{3}$ \\ ${ }^{1}$ Laboratory of Biogeography, Institute of Geography RAS, 29/4 Staromonetny Lane, 119017 Moscow, Russia. \\ E-mail: pchelkin@igras.ru \\ ${ }^{2}$ Department of Botany and Plant Physiology, Petrozavodsk State University, 33 Lenin Str., 185910 Petrozavodsk, Russia. \\ E-mail: tarasova1873@gmail.com \\ ${ }^{3}$ Department of Botany, Northern (Arctic) Federal University, 17 Severnaya Dvina Emb., 163002 Arkhangelsk, Russia. \\ E-mail: valekzhanin13@gmail.com
}

\begin{abstract}
The paper presents the first data on lichen diversity in the Kenozersky National Park (Arkhangelsk Region, Northwest Russia). As a result of the study, 263 species and 1 subspecies of lichens and allied fungi were found in the southern part of the national park. Seventeen lichen species are reported for the first time for Arkhangelsk Region. Biatora albidula is a new species for Northwest European Russia. Two recorded species are included in the Red Data Book of Russian Federation and 7 in the Red Data Book of Arkhangelsk Region. Pycnothelia papillaria can be recommended for inclusion to the Red Data Book of Arkhangelsk Region.
\end{abstract}

Keywords: middle boreal subzone, new records, protected area, taiga forests

\section{INTRODUCTION}

Currently, in the context of significant environmental transformation, the role of specially protected natural areas in the conservation and maintenance of the main types of natural landscapes, communities and biodiversity is becoming more and more important (Gray et al., 2016; Berteaux et al., 2018). Lichens are an integral component of boreal ecosystems known to be highly sensitive to habitat conditions (Nash, 2008). Lichenological studies of protected areas are traditionally of great interest due to the high preservation status of natural communities and their significant role in maintaining biodiversity and conservation of rare and protected species (Dymytrova et al., 2014). Lichen diversity can serve as an effective indicator for biomonitoring in natural ecosystems (Khastini et al., 2019). It is also used for assessing the scale of dynamic processes associated with both global and regional factors (McMullin et al., 2016; Brzeziecki, 2017), forecasting the state of ecosystems and developing effective measures for their conservation (Waser et al., 2007; Zhang et al., 2016).

The Kenozersky National Park (KNP) was established in 1991 with the purpose to conserve the natural, historical, and cultural heritage of the Russian North. It is located in Kargopolsky and Plesetsky districts of Arkhangelsk Region near the south-eastern border of the Republic of Karelia. The territory of the park has a long history of human use in the past and therefore differs from other protected areas in Northwest Russia by its high recreational attractiveness and the presence of vast anthropogenic landscapes formed over many centuries. There are a lot of monuments of wooden architecture. In 2004 , the park was recognized by UNESCO as a biosphere reserve included in the World Network of Biosphere Reserves.

Lichen diversity of Arkhangelsk Region is still poorly studied compared to other regions of Russia (Tarasova et al., 2015, 2016). Similarly, the lichen biota of KNP is not properly studied. The aim of this study is to take an inventory of lichen diversity in the southern part of the Kenozersky National Park (Arkhangelsk Region, NW Russia).

\section{MATERIALS AND METHODS}

The study area is located in the south-western part of Arkhangelsk Region in the south of the Kenozersky National Park (Fig. 1). The total area of the park is 139.7 thousand hectares. Its territory extends from $61^{\circ} 40^{\prime}$ to $62^{\circ} 10^{\prime} \mathrm{N}$ and from $37^{\circ} 50^{\prime}-38^{\circ} 00^{\prime}$ to $38^{\circ} 10^{\prime}-38^{\circ} 30^{\prime} \mathrm{E}$. The climate of the region is moderately continental. The average annual air temperature is $1.5^{\circ} \mathrm{C}$ in the south and $1.3^{\circ} \mathrm{C}$ in the north of the national park. The average annual precipitation is 597 


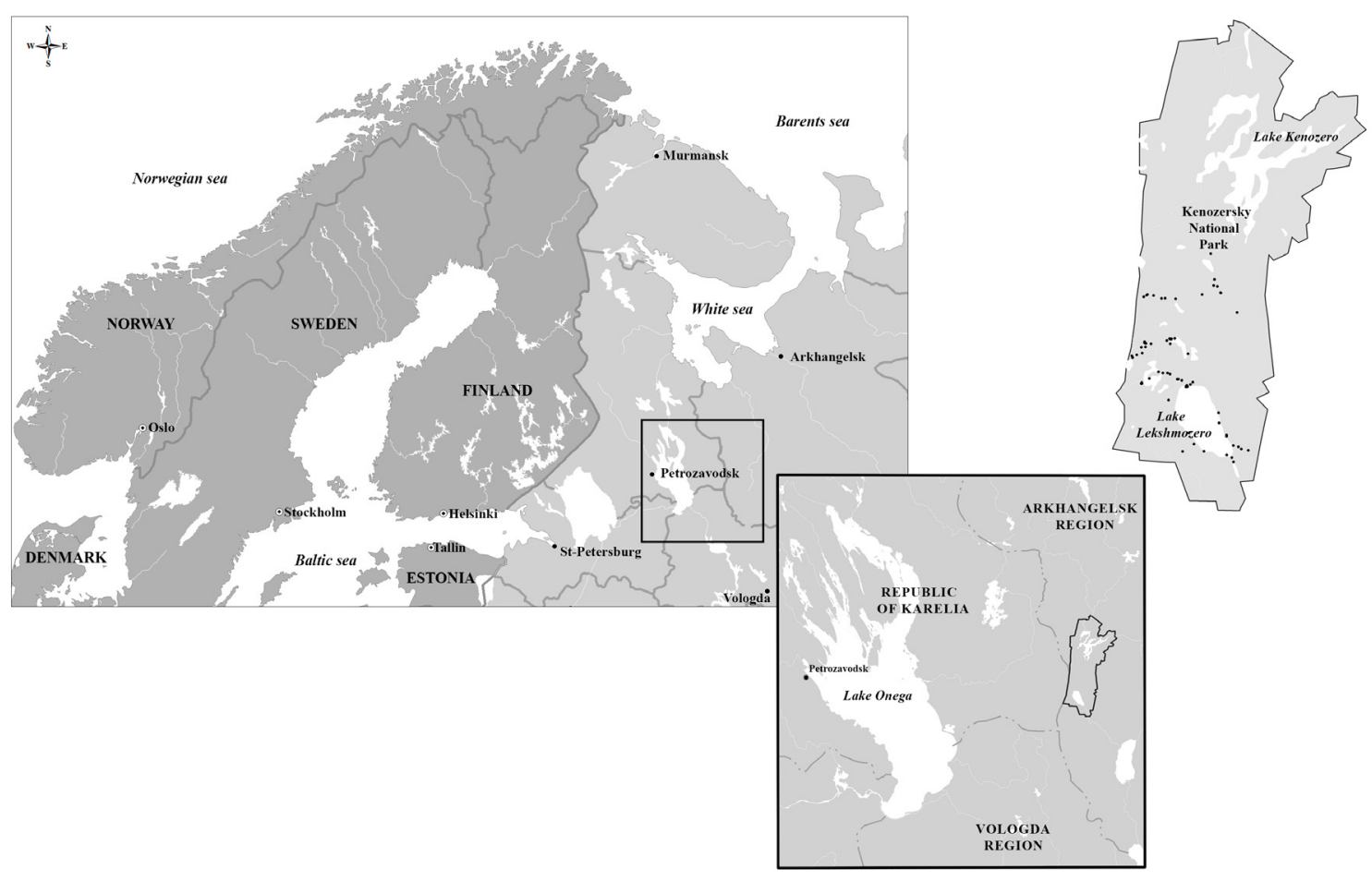

Fig. 1. The location of the study area (the Kenozersky National Park, Arkhangelsk Region, Northwest Russia). Black points indicate the sampling sites.

and $564 \mathrm{~mm}$, respectively. The growing season lasts for about 130 days. Frost-free period is 108 days. A stable snow cover lasts for 160 days (Razumovskaja et al., 2012).

The territory of the national park is characterized by high natural heterogeneity. Two important natural boundaries run along it: between the Baltic Shield and the East European Platform (from southwest to northeast), and the watershed between the basins of the Atlantic and Arctic oceans (from north to south; Kulikova et al., 2012). The so-called "Maselga Point" from the southern part of park is particularly unique, cause its located in a place of intersection of two boundaries: the Atlantic-Arctic watershed and the water line between Fennoscandia and the Russian Plain (Kulikov et al., 2015).

The area of the national park stands out against the background of the plain environment with a complex geological structure and various forms of relief. The marginal part of the Baltic Shield, composed of Paleo- and Mesoarchean gneisses and granitoids, runs along the northern and northwestern sides of the national park. The south, east, and northeast of the national park are located within the East European Platform, in the area of Vendian and Paleozoic sedimentary rocks (limestones and dolomites; Kulikova et al., 2012; Razumovskaja et al., 2012). Crystalline rocks come to the surface in the form of eskers or are covered by a cover of quaternary deposits of the Valdai glaciation. The height differences rarely exceed $200 \mathrm{~m}$; the average height above sea level is 100-120 m (Kalutskov, 2017; Kulikova \& Kulikov, 2017). There are two large lakes in the Kenozersky National Park: Lake Lekshmozero in the south of the park and Lake Kenozero in the north (Razumovskaja et al., 2012). Podzolic soils, common for the middle taiga, occupy about $75 \%$ of the national park area. Boggy soils of various types spread on the rest $25 \%$ of the area (Kalutskov, 2017).

The vegetation in the Kenozersky National Park is typical for the middle taiga subzone. Forest 
cover $76 \%$ of the park territory (Torkhov, 2012). Herb-rich spruce forests and their derivates such as birch and aspen forests dominate. Sphagnum raised and transitional bogs, as well as lowland bogs fed by springs are common. The Kenozero part of the park is characterized by the predominance of bilberry pine and spruce forests, as well as lingonberry pine forests. Herbrich pine forests, spruce and aspen forests are confined to the steep slopes of moraine ridges, herb-rich spruce and aspen forests are located at their foot. Coastal vegetation is diverse along the shores of water bodies, and aquatic vegetation in shallow waters (Razumovskaja, 2018).

The vegetation of the park has been largely influenced by human activities in the past. The beginning of agricultural practices in the Kenozero region dates back to the $10^{\text {th }}$ century. From that time until the middle of the $20^{\text {th }}$ century the territory was densely, and most of the land presently covered by forests was used for agriculture (Razumovskaja et al., 2012). To a large extent, the forests of the national park are standing on previously burned areas resulted from slash-and-burn activities. It is evidenced by the pyrogenic origin of almost half of the forests. Thus, forests covering area of 49 thousand hectares are 80 to 100 years old. Intact forests older than 160 years occupy an area of only about 5.8 thousand hectares and have been preserved as fragments in low-lying wetlands unsuitable for agricultural activities (Torkhov, 2012). These forests are paludified spruce and pine forests with trees of age between 160 and 350 years (Byzova, 2016).

The field work was carried out by authors during 3 expeditions: in July 2011 (by V. Tarasova), in May 2018 (by A. Valekzhanin) and in August 2018 (by A. Pchelkin). Specimens were collected in the Kargopol sector of the national park in natural forest communities of different types and anthropogenic landscapes (Fig. 2).

The lichen diversity was studied on linear routes, which were developed based on forest plantation maps and satellite images to cover as many diverse habitat types as possible. To estimate the lichen species richness, various types of substrates were examined including trunks and branches of trees, shrubs, deadwood, mosses, soil and primitive soil covering the surface of the stones, rotting wood and stumps, dead trees, boulders and also anthropogenic formations (buildings).

The collected material, a total of $\sim 1230$ lichen specimens, was identified using a standard microscopic technique and spot tests. The 22 specimens of the genus Cladonia and sterile crustose specimens were identified by a standard technique of thin-layer chromatography (TLC) in the Laboratory of Experimental Botany of Petrozavodsk State University (Petrozavodsk) using solvent systems A, B and C (Orange et al., 2001).

The cited specimens are deposited in the herbaria of Petrozavodsk State University (PZV), Institute of Geography RAS (IGRAS), Institute of Global Climate and Ecology (IGCE) and in the Kenozersky National Park.

\section{RESULTS AND DISCUSSION}

The 263 species and 1 subspecies of lichens and allied fungi (including 4 lichenicolous fungi and 3 non-lichenized fungi) belonging to 48 families and 101 genera were found in the southern part of the Kenozersky National Park. Crustose species were dominant (152 species), contributing to $59 \%$ to the total number of lichens. 53 fruticose $(21 \%)$ and 51 foliose $(20 \%)$ species were recorded.

\section{Notes on new, rare or Red Data Book species}

Among the recorded species 17 lichens are reported for Arkhangelsk Region for the first time: Absconditella lignicola, Arthonia apatetica, Biatora albidula, Biatora chrysantha, B. meiocarpa, Calicium tigillare, Candelariella lutella, Chaenotheca chlorella, Felipes leucopellaeus, Lecanora umbrina, Melanohalea exasperata, Peltigera hymenina, Phaeophyscia nigricans, $P$. orbicularis, Placynthiella dasaea, Pycnothelia papillaria, and Xylopsora caradocensis. Biatora albidula is a new species for Northwest European Russia. Four species (Candelariella aurella, Megaspora verrucosa, Myriolecis crenulata, $M$. dispersa) have been recorded earlier only from Arctic islands of Arkhangelsk Region.

Lobaria pulmonaria and Bryoria fremontii are included in the Red Data Book of Russian Federation. Seven recorded species (Acolium karelicum, Bryoria fremontii, Chaenotheca brachypoda, C. phaeocephala, Evernia divaricata, Lobaria 
A

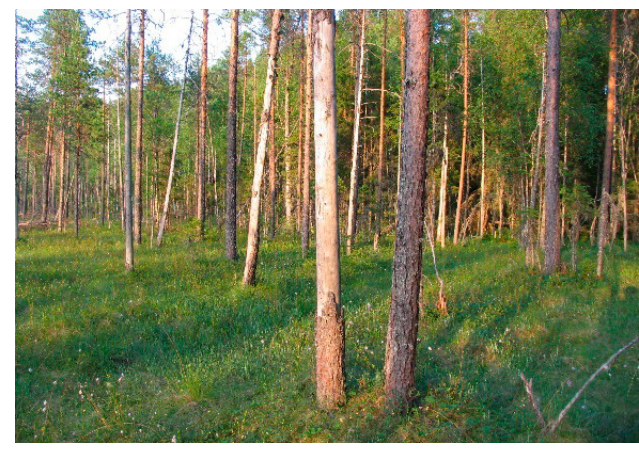

C

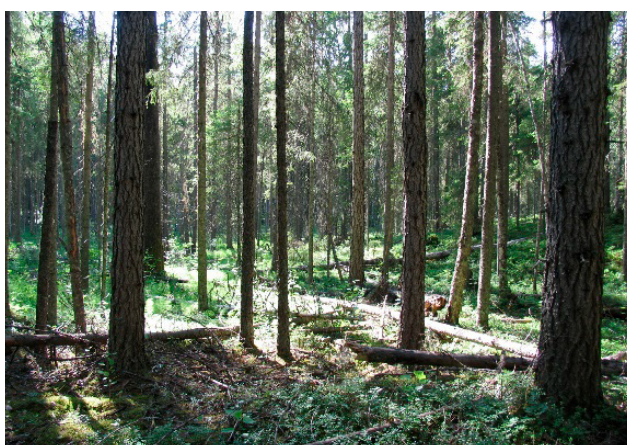

$\mathbf{E}$

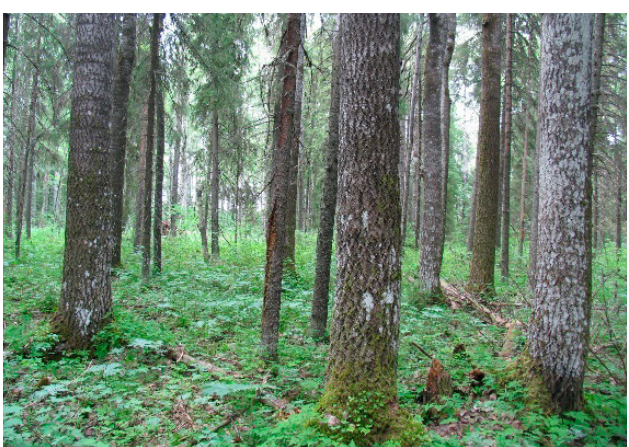

G

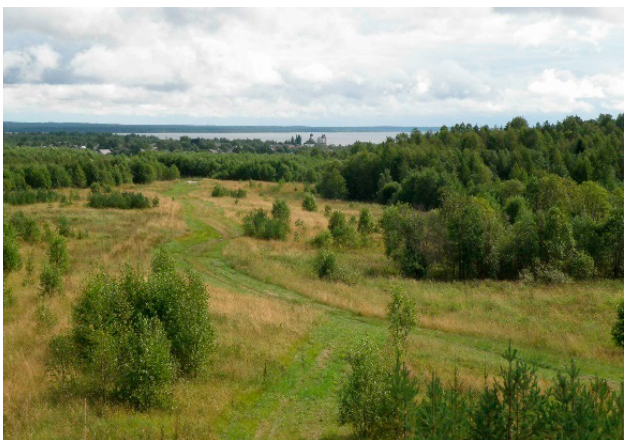

B

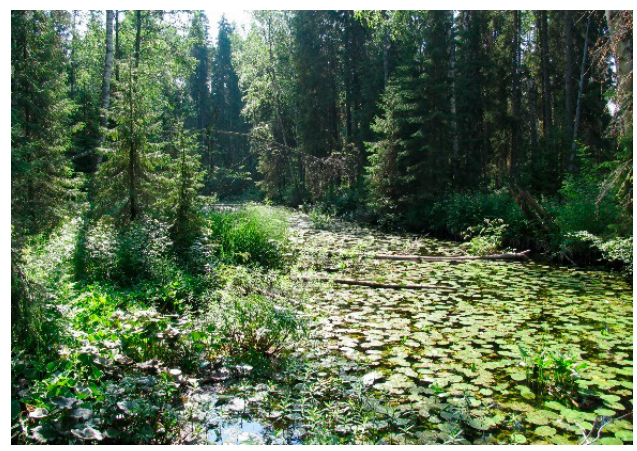

D

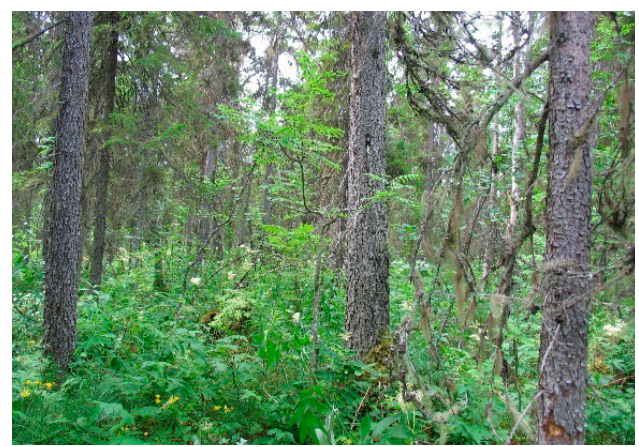

$\mathbf{F}$

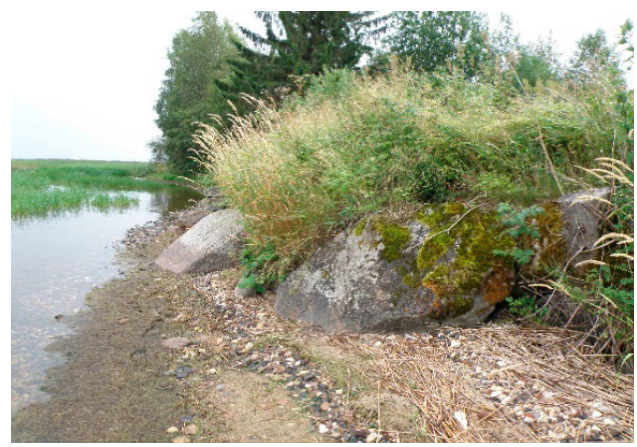

$\mathbf{H}$

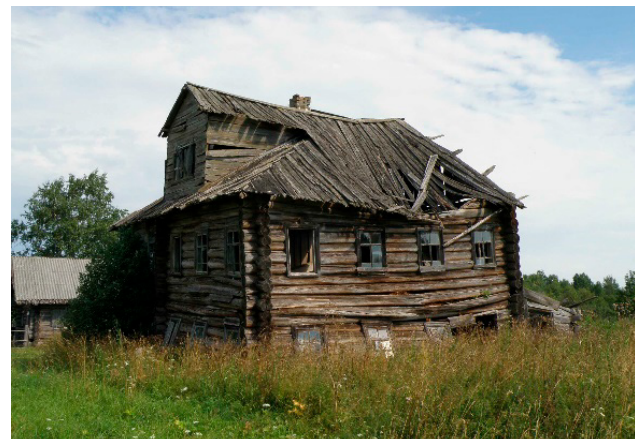

Fig. 2. Studied habitats: a - paludified peatmoss pine forest (locality № 5); b - paludified floodplain herb-rich spruce forest (locality № 7); c - bilberry feathermoss larch-spruce-pine forest (locality № 16); d - paludified herb-rich spruce forest (locality № 20); e - herb-rich aspen forest (locality № 22); f - individual boulders (locality № 25); $\mathrm{g}$ - the road along the route "Ancestral Trail" (locality № 35); $\mathrm{h}$ - roof of an abandoned house in Ivshinskaya village (locality № 47). 
pulmonaria, Pseudevernia furfuracea) are included in the Red Data Book of Arkhangelsk Region (2020). Four species (Acolium inquinans, Chaenotheca stemonea, Hypogymnia vittata, Rostania occultata) are included in the list of taxa of Arkhangelsk Region that need special attention to their status in the natural environment and are recommended for biological monitoring (The Red Data Book of Arkhangelsk Region, 2020). Pycnothelia papillaria can be recommended for inclusion in the Red Data Book of Arkhangelsk Region. This species gravitates towards oceanic and suboceanic regions, is objectively rare in northwestern Russia, and is included in the Red Data Books of Leningrad Region (2000) and the Republic of Karelia (2020).

\section{Lichen substrates and habitats in study sites}

The substrate preferences analysis of lichens from studied communities revealed the predominance of the epiphytic group (corticolous and lignicolous) (185 species, 71\%). Among the studied phorophytes, the richest lichen diversity (93 species, 36\% of the lichen flora) was observed on the aspen trees. On the trunks and branches of spruce 68 species $(26 \%)$ were found, on pine -63 species (24\%), on willow -61 species $(24 \%)$, on birch - 55 species $(21 \%)$, on larch -47 species $(18 \%)$, on alder -38 species $(15 \%)$, on bird-cherry tree -35 species $(14 \%)$, on rowan -34 species $(13 \%)$, on juniper -16 species $(6 \%)$. On treated wood of buildings were presented 60 species, on dead wood -41 species.

Terricolous lichens are the second dominant group (33 species, 13\%). The saxicolous lichens are represented by the smallest number of species ( 30 species, $12 \%$ ), but characterized by high substrate specificity ( 25 species were found on stones only). The largest number of lichen species was found on granite stones (23 species), and they were different from lichens found on the concrete walls (11 species). For example, species of the genera Rhizocarpon, Porpidia, Tephromela were found only on granite stones, while species Calogaya decipiens, Myriolecis crenulata, $M$. dispersa were observed on concrete walls. The Protoparmeliopsis muralis was found on limestone. Several species $(17,7 \%)$ were relatively nonspecific for substrates.

It should be noted that the identified species diversity of lichens and allied fungi for the Kenozersky National Park is still incomplete. For example, neighboring protected areas host significantly more species, than presently recorded for the territory of the Kenozersky National Park (Appendix 1). Further research of lichen diversity in the Kenozersky National Park is required, including its northern part, as well as earlier collections should be revised.

\section{LIST OF SPECIES}

Taxa are arranged in alphabetical order; nomenclature of lichens, lichenicolous and nonlichenized fungi follows Nordin et al. (2011). For each species the localities, habitat types and substrates are listed. Lichen substances are given for TLC-analyzed specimens.

Abbreviations and symbols: \# - lichenicolous fungi; + - non-lichenized fungi; ! - new species for mainland area of Arkhangelsk Regoin; !! new species for Arkhangelsk Region (including arctic islands); RR - species included in the Red Data Book of Russian Federation (2008); RA - species included in the Red Data Book of Arkhangelsk Region (2020); RA(bs) - species included in the list of taxa of Arkhangelsk Region that need special attention to their state in the natural environment and are recommended for biological surveillance. Localities for species are marked by the numbers of sampling plots (1-68) according to Appendix 2.

!! ABsconditella lignicola Vězda \& Pišút - 45: on standing dead birch wood (Betula pendula Roth.). This is a common boreal species reported from most regions of Russia (Urbanavichus, 2010). Distribution in neighboring territories: the Republic of Karelia (Fadeeva et al., 2007), Komi Republic (Hermansson et al., 1998), Leningrad Region (Kuznetsova et al., 2007), and Murmansk Region (Urbanavichus et al., 2008).

ACAROSPORA MOENIUM (Vain.) Räsänen - 35: on concrete wall; 36: on stone.

Acolium inguinans (Sm.) A. Massal. - 20: on snag of spruce (Picea sp.). RA(bs).

Acolium Karelicum (Vain.) M. Prieto \& Wedin - 7: on snags and trunk of spruce. RA.

Alectoria sarmentosa (Ach.) Ach. - 3, 39: on snags of spruce.

ALYXORIA VARIA (Pers.) Ertz \& Tehler - 4: on dead aspen bark (Populus tremula L.). 
Amandinea Punctata (Hoffm.) Coppins \& Scheid. 13: on birch bark; 45: on aspen and birch bark.

!! ARthonia apatetica (A. Massal.) Th. Fr. -61: on wood of standing dead spruce. This is a common boreal species reported from most regions of Russia (Urbanavichus, 2010). Distribution in neighboring territories: the Republic of Karelia (Fadeeva et al., 2007), Komi Republic (Hermansson et al., 1998), Leningrad Region (Kuznetsova et al., 2007), and Murmansk Region (Urbanavichus et al., 2008).

ARTHONIA DISPUNCTA Nyl. - 66: on bark of willow (Salix spp.).

ARTHONIA MEDIELLA Nyl. - 45: on bark of birch.

ARthonia Radiata (Pers.) Ach. - 49: on bark of aspen and old bird-cherry tree (Padus avium Mill.).

AsPicilia CinerEa (L.) Körb. - 25, 35, 56: on stone.

Athallia holocarpa (Hoffm.) Arup et al. - 26: on concrete wall.

Athallia pyracea (Ach.) Arup et al. - 24, 54: on bark of aspen.

BAeOmyces Rufus (Huds.) Rebent. - 30: on sandy soil.

!! BiATORA ALBidula Willey in Tuck. - 14: on bark of aspen. This species was previously known in Russia only from Republic of Altai, Chelyabinsk Region, Khabarovsk Territory, Trans-Baikal Territory (Palice et al., 2013), and Kostroma Region (Urbanavichus, 2019). Here it is reported first time for Northwest European part of Russia. So far it was reported from Germany, Norway, Sweden, and USA (Palice et al., 2013). Conf. D. Himelbrant.

Biatora Albohyalina (Nyl.) Bagl. \& Carestia - 28: on bark of aspen.

!! Biatora Chrysantha (Zahlbr.) Printzen - 8: on bark of standing dead alder (Alnus incana (L.) Moench). This is a common boreal species reported from most regions of Russia (Urbanavichus, 2010). Distribution in neighboring territories: the Republic of Karelia (Fadeeva et al., 2007), the Komi Republic (Hermansson et al., 1998), Leningrad Region (Kuznetsova et al., 2007), and Murmansk Region (Urbanavichus et al., 2008).

BIATORA EFFLORESCENS (Hed1.) Räsänen - 8: on bark of standing dead alder; 20: on bark of willow; 29: on bark of rowan (Sorbus aucuparia L.).
Biatora Globulosa (Flörke) Fr. - 29: on bark of rowan.

Biatora HELVOLA Körb. ex Hellb. - 5, 64: on bark of pine (Pinus sylvestris L.); 20: on bark of willow; 22, 24, 41: on bark of spruce and birch; 53: on bark of juniper (Juniperus communis L.).

!! Biatora MEIOCARPa (Nyl.) Arnold - 24: on bark of birch. This is a common boreal species reported from most regions of Russia (Urbanavichus, 2010). Distribution in neighboring territories: the Republic of Karelia (Fadeeva et al., 2007), Komi Republic (Hermansson et al., 1998), Leningrad Region (Kuznetsova et al., 2007), and Murmansk Region (Urbanavichus et al., 2008).

Biatora OCELliformis (Nyl.) Arnold - 8, 49: on bark of standing dead alder; 20, 64: on bark of willow; 29: on bark of birch; 54: on bark of pine; 49, 52: on bark of bird-cherry tree.

Biatora Pallens (Kullh.) Printzen - 8: on bark of standing dead alder.

BiATORA VERNALIS (L.) Fr. - 28: on moss growing on bark of aspen.

Bilimbia microcarpa (Th. Fr.) Th. Fr. - 4: on bark of standing dead aspen.

Bilimbia sabuletorum (Schreb.) Arnold - 49, 61: on bark of aspen.

BRYORIA FREMONTII (Tuck.) Brodo \& D. Hawksw. - 5: on bark of pine; 44: on branches of spruce. RR, RA.

BRYORIA FURCELLATA (Fr.) Brodo \& D. Hawksw. 1, 3-14, 16, 19-24, 27-29, 32-34, 37-44, 49, 51: on branches and trunks of spruce, pine and birch.

BRYORIA FusCEsCENS (Gyeln.) Brodo \& D. Hawksw. - 1, 3-16, 19-24, 27-29, 32-34, 37-44, 50-51, 60, 62: on branches and trunks of deciduous and coniferous trees.

BRYORIA NADVORNIKIANA (Gueln.) Brodo \& D. Hawksw. $-3,7,10,20,54$ : on branches of spruce; 44: on branches of birch; 57: on decaying aspen; 60: on bark of larch (Larix sibirica Ledeb); 51, 53: on bark of pine.

Buellia Disciformis (Fr.) Mudd - 15, 49, 56, 67: on bark of willow, alder, bird cherry tree and on wood.

BuELLIA ERUBESCENS Arnold - 20, 64: on bark of willow; 29: on bark of rowan; 49: on decaying wood. 
BuElLIA GRISEOviRENS (Turner \& Borrer ex Sm.) Almb. - 53: on bark of old bird cherry tree.

Calicium adspersum Pers. - 20: on bark of spruce.

Calicium denigratum (Vain.) Tibell - 15, 51: on treated wood.

Calicium glaucellum Ach. - 2: on treated wood; 61: on wood of old pine.

Calicium Parvum Tibell - 51: on wood of old pine.

!! Calicium tigillare (Ach.) Pers. - 44: on wood of old standing dead spruce. Distribution in neighboring territories: the Republic of Karelia (Fadeeva et al., 2007), Komi Republic (Hermansson et al., 1998), Leningrad Region (Kuznetsova et al., 2007), and Murmansk Region (Urbanavichus et al., 2008). Species included in the Red Data Book of the Republic of Karelia (2020).

Calicium trabinellum (Ach.) Ach. - 2, 13, 15, 51, 53: on treated wood.

CAlicium VIRIDE Pers. $-1,50$ : on bark of spruce; 15: on treated wood; 16: on bark of larch.

!! Calogaya decipiens (Arnold) Arup et al. - 26: on concrete wall. This species reported from most regions of Russia (Urbanavichus, 2010). Previously known in Arkhangelsk Region without exact location (Handbook.., 2004). Species included in the Red Data Book of the Republic of Karelia (2020).

Caloplaca cerina (Hedw.) Th. Fr. - 24: on bark of aspen; 49: on bark of bird-cherry tree; 56 : on bark of willow.

! Candelariella aurella (Hoffm.) Zahlbr. - 26: on concrete wall; 66: on bark of willow. This is a common boreal species reported from most regions of Russia (Urbanavichus, 2010). Previously known in Arkhangelsk Region only from its Arctic part (Deichmann-Branth, 1885; Heuglin, 1874).

!! CANDElariella lutella (Vain.) Räsänen - 24: on branches of aspen. This is a common boreal species reported from most regions of Russia (Urbanavichus, 2010). Distribution in neighboring territories: the Republic of Karelia (Fadeeva et al., 2007), Komi Republic (Hermansson et al., 1998), Leningrad Region (Kuznetsova et al., 2007), and Murmansk Region (Urbanavichus et al., 2008).

Candelariella vitellina (Hoffm.) Müll. Arg. - 15: on treated wood; 24,35 , 46: on stones, treated wood and bark of aspen.
Candelariella Xanthostigma (Ach.) Lettau - 13: on bark of birch; 18: on roofing paper.

Catinaria atropurpurea (Schaer.) Vězda $\&$ Poelt - 3: on branches of spruce; 57 : on bark of fallen dead aspen.

Cetraria islandica (L.) Ach. - 30-32, 55: on soil.

CETRARIA SEPINCOla (Ehrh.) Ach. - 15: on branches of spruce; 16: on branches of larch; 24: on branches of birch; 55: on treated wood.

Chaenotheca BRachypoda (Ach.) Tibell - 4: on bark of standing dead aspen; 8: on bark of willow. RA.

Chaenotheca Bruneolla (Ach.) Müll. Arg. - 2, 12-13: on treated wood.

!! Chaenotheca Chlorella (Ach.) Müll. Arg. - 15: on treated wood. This is a boreal species reported from most regions of Russia (Urbanavichus, 2010). Distribution in neighboring territories: Republic of Karelia (Fadeeva et al., 2007), Komi Republic (Hermansson et al., 1998), Leningrad Region (Stepanchikova et al., 2007), and Murmansk Region (Urbanavichus et al., 2008). Species included in the Red Data Book of Murmansk Region (2014).

ChaENotheca CHRYsocephala (Turner ex Ach.) Th. Fr. $-7,15,20$ : on bark of spruce; 9: on bark of larch; 15, 17: on treated wood; 50 - on bark of old spruce.

ChaEnotheca FerRuginea (Turner ex Sm.) Mig. - 5, $33,40,51,54$ : on bark of pine; 7,37 : on bark of spruce and deadwood; 9, 16, 60: on bark of larch; 20: on bark of spruce; 54: on bark of old aspen.

Chaenotheca furfuracea (L.) Tibell - 4, 12: on soil on roots of fallen dead spruce trees.

Chaenotheca PhaEocephala (Turner) Th. Fr.- 13: on treated wood. RA.

Chaenotheca stemonea (Ach.) Müll. Arg.- 43: on base trunk of spruce. RA(bs).

Chaenotheca subroscida (Eitner) Zahlbr. - 50: on bark of old spruce; 54: on bark of old pine.

Chaenotheca trichialis (Ach.) Th. Fr. - 12, 50: on bark of spruce; 16: on bark of larch; 20, 33: on bark of willow; 49: on treated wood; 61: on bark of old pine. 
\#Chaenothecopsis consociata (Nádv.) A. F. W. Schmidt - 54: on thalli of Chaenotheca chrysocephala on bark of old pine.

\#ChaENothecopsis ePithallina Tibell - 16: on thalli of Chaenotheca trichialis on bark of larch; 20: on thalli of Chaenotheca trichialis on bark of willow.

\#CHAENOTHECOPSIS PUSILla (Ach.) A. F. W. Schmidt 15, 49: on treated wood; 20: on wood of willow.

\#ChaEnothecopsis SAVonica (Räsänen) Tibell - 9: on bark of larch.

Circinaria CaEsiocinerea (Nyl. ex Malbr.) A. Nordin et al. $-25,36$ : on stone.

Cladonia amaurocraea (Flörke) Schaer. - 30: on sandy soil.

Cladonia arbuscula (Wallr.) Flot. - 2, 46: on treated wood; 30: on sandy soil; 31, 55: on bare soil; 33, 34: on mossy stumps.

Cladonia BACILliformis (Nyl.) Glück -15, 24: on base of trunk of birch, 51 ; on base of trunk of pine; 49, 67: on treated wood.

Cladonia botrytes (K. G. Hagen) Willd. - 2, 13, $15,17-18,45,49,53$ : on treated wood; 24 : on base of trunk of birch.

Cladonia Cenotea (Ach.) Schaer. - 12, 49: on deadwood; 15: on wooden buildings; 30: on sandy soil; 29, 34, 54, 59-61, 67: on base of trunk trees.

Cladonia Chlorophaea (Flörke ex Sommerf.) Spreng. $-24,50,55,57-59,65$ : on base of trunks of birch, on dead wood, on soil, on base of old spruce. The specimens contain fumarprotocetraric acid.

Cladonia coniocraea (Flörke) Spreng. - 2-24, $27-29,49,53-55,60,65$ : on base of trunks of trees, deadwood and treated wood; 56 : on soil.

Cladonia Cornuta (L.) Hoffm. - 2-22, 31-34, 55: on soil, base of trunks of trees, deadwood and treated wood.

Cladonia CRISPATA (Ach.) Flot. - 18: on treated wood; 30, 54: on sandy soil.

Cladonia CYANIPEs (Sommerf.) Nyl. - 67: on dead wood.
Cladonia deformis (L.) Hoffm. - 2-24, 29-34: on base of trunks of trees, deadwood and treated wood; 55: on soil.

Cladonia digitata (L.) Hoffm. - 1-23, 29-34, 51, 54, 60: on base of trunks of trees, deadwood and treated wood.

Cladonia fimbriata (L.) Fr. - 17: on sandy soil; 24, 32-34: on base of trunk of trees.

Cladonia furcata (Huds.) Schrad. - 31: on soil.

Cladonia GRACIlis subsp. TuRBINATA (Ach.) Ahti17: on sandy soil; $49,58,67$ : on soil, deadwood and stone with thin soil layer.

Cladonia GRayi G. Merr. ex Sandst. - 56: on soil. The specimen contains grayanic acid.

Cladonia macilenta Hoffm. - 2, 18: on treated wood.

Cladonia mitis Sandst. - 18; on treated wood; 27, $32,55,64$ : on soil, deadwood and stone with thin soil layer.

Cladonia Ochrochlora Flörke - 2: on treated wood; 49: on deadwood.

Cladonia Phyllophora Hoffm. - 15, 27, 30, 55: on soil.

Cladonia Pleurota (Flörke) Schaer. - 24, 33, 53: on base of trunk of trees.

Cladonia pyxidata (L.) Hoffm. - 27, 30: on soil and on base of pine trunk.

Cladonia Rangiferina (L.) F. H. Wigg. - 2, 13, 17-18: on wooden buildings; 9, 30, 32, 40, 49, $55-56,67$ : on soil.

CLADONIA REI Schaer. - 24: on base of trunk of birch.

Cladonia stellaris (Opiz) Pouzar \& Vězda - 2, 9, 13, 17-18, 27, 40, 67: on soil, deadwood and treated wood.

Cladonia stygia (Fr.) Ruoss - 68: on sphagnum.

Cladonia subulata (L.) Weber ex F. H. Wigg. 30: on soil.

Cladonia sulphurina (Michx.) Fr. - 2-20, 27, 41, 45: on bases of trees, deadwood and treated wood.

Cladonia uncialis (L.) Weber ex F. H. Wigg. - 30: on soil. 
Cladonia verticillata (Hoffm.) Schaer. - 30, 55: on soil.

Cliostomum leprosum (Räsänen) Holien \& Tønsberg - 20: on bark of spruce.

Collema Furfuraceum (Arnold) Du Rietz - 20-21, 28: on bark of aspen.

DeRmatocarpon miniatum (L.) W. Mann - 35: on stone.

Dibaeis BAEOMYces (L. f.) Rambold \& Hertel - 30: on soil.

DiplOsChistes scRuPOSUs (Schreb.) Norman - 25: on mossy stone.

EVERNIA DIVARICATA (L.) Ach. - 3: on branches of spruce. RA.

EVERNIA MESOMORPHA Nyl. - 1-20, 23-24, 27-29, $32-34,37-44,51,54$ : on bark of trees, deadwood, treated wood.

EVERNIA PRUNASTRI (L.) Ach. - 14, 29, 49: on bark of alder.

!! Felipes leucopellaeus (Ach.) Frisch \& G. Thor 42: on bark of old alder. This is a species reported only from Northern European part of Russia (Urbanavichus, 2010). Distribution in neighboring territories: the Republic of Karelia (Hermansson et al., 2002), Komi Republic (Hermansson et al., 1998), and Leningrad Region (Kuznetsova et al., 2007).

FuscidEA PUSILLA Tønsberg - 8: on bark of standing dead alder; 43: on bark of spruce. The specimens contain divaricatic acid.

GRAPHIS SCRIPTA (L.) Ach. - 49: on bark of aspen.

Gyalecta Fagicola (Hepp ex Arnold) Kremp. - 11, 14: on bark of aspen; 21: on bark of birch; 20: on bark of willow.

Gyalecta truncigena (Ach.) Hepp - 22: on bark of aspen.

Gyalolechia flavorubescens (Huds.) Søchting et al. -28: on bark of aspen.

Hypocenomyce scalaris (Ach.) M. Choisy - 2, 9, $13,15-18,24,27,45-46$ : on bases of trees of different species, treated wood and burnt wood, bark of pine and birch.

HyPogymnia PHYSODEs (L.) Nyl. - 1-67: on trunks, branches, decaying wood of trees of different species, treated wood and stones.
Hypogymin tubulosa (Schaer.) Hav. - 1-47, 49, 67: on trunks, branches, decaying wood of trees of different species, treated wood.

Hypogymnia vitTata (Ach.) Parrique - 7: on bark of birch. RA(bs).

ICMADOPHILA ERICETORUM (L.) Zahlbr. - 7, 44: on deadwood of old stamps.

IMSHAUGia Aleurites (Ach.) S. L. F. Mey. - 5, 10, 33-34, 51: on bark and branches of pine; 16: on branches of larch.

JAPEWIA TORNOËNSIS (Nyl.) Tønsberg - 42: on branches of spruce.

LeCANia CyRTElla (Ach.) Th. Fr. - 29: on bark of rowan; 67: on bark of willow.

LeCANia NaEgeli (Hepp) Diederich \& van den Boom - 1: on bark of standing dead aspen; 29: on bark of rowan; 64, 67: on bark of willow.

LeCANora Aitema (Ach.) Hepp - 65: on fallen dead tree.

LeCANora AlBellula (Nyl.) Th. Fr. var. AlBellula56: on bark of willow.

LECANORA ALLOPHANA Nyl. $-1,11,20-21$ : on bark of aspen; 24, 29, 49, 54: on bark of aspen, rowan, birch.

LeCANora ARgentata (Ach.) Malme - 24: on bark of aspen; 49: on bark of bird-cherry tree.

LECANORA CARPINEA (L.) Vain. - 24: on bark of aspen; 49: on bark of bird-cherry tree.

LECANORA CATEILEA (Ach.) A. Massal. - 24: on bark of aspen; 52: on bark of old bird-cherry tree.

LECANORA CENISIA Ach. - 25, 36: on stones.

LECANORA CHLAROTERA Nyl. - 14, 24: on bark of aspen.

LECANORA CIRCUMBOREALIS Brodo \& Vitik. - 15, 17 : on treated wood.

LECANORA HYPOPTA (Ach.) Vain. - 5: on snags of pine; 44: on bark of standing dead birch.

LECANORA INTRICATA (Ach.) Ach. - 25: on stones.

LeCANORA PHAEOSTIGma (Körb.) Almb. - 10: on branches of pine; 12: on branches of spruce; 51,53 : on bark of pine.

LECANORA POLYTROPA (Ehrh. ex Hoffm.) Rabenh. 25, 36: on stones. 
LeCANora populicola (DC.) Duby - 20: on bark of willow; 24, 41: on bark of aspen.

LECANORA PULICARIS (Pers.) Ach. - 10: on bark of pine; 16: on bark and branches of larch; 29: on bark of rowan; 49, 65: on treated wood; 52 : on bark of old bird-cherry tree.

LECANORA SYMMicTA (Ach.) Ach. - 2, 65: on treated wood; 20, 56: on bark of willow; 24, 33: on bark and branches of birch; 49; on bark of alder; 54 : on bark of old aspen.

!! Lecanora umbrina (Ach.) A. Massal. - 18: on roofing paper. Distribution in neighboring territories: the Republic of Karelia (Fadeeva et al., 2007), Leningrad Region (Kuznetsova et al., 2007), and Murmansk Region (Urbanavichus et al., 2008).

LeCANora VARIa (Hoffm.) Ach. - 15, 18, 47: on treated wood.

LECIDEA ERYTHROPHAEA Flörke ex Sommerf. - 20, 24, 49, 63: on bark of aspen; 49: on bark of alder.

LECIDEA LEPRARIOIDES Tønsberg - 16: on bark of larch.

LECIDEA NYLANDERI (Anzi) Th. Fr. - 3, 20, 50, 54: on bark of spruce; $5,6,53-54$ : on bark of pine; 16: on bark of larch; 27: on bark of spruce and pine; 49: on bark of treated wood; 67: on bark of birch; 49, 54: on bark of old aspen.

LECIDEA TURGIDULA Fr. - 3, 33-34: on bark of spruce; $5,23,53,61$ : on bark of pine.

Lecidella elaeochroma (Ach.) M. Choisy - 1, 11, 14, 20-21, 24, 49: on bark of aspen.

LECIDELLA EUPHOREA (Flörke) Hertel - 24, 28: on bark and branches of aspen.

LEPRA ALBESCENS (Huds.) Hafellner - 28: on bark of aspen.

LEPRA AMARA (Ach.) Hafellner - 3, 8, 10-11, 14, $16,20,22,41-43,52,63$ : on bark and wood of trees of different species.

LEPRA OPHTHALMIZA (Nyl.) Hafellner - 8: on standing dead alder; 20: on bark of willow.

LEPRARIA ELOBATA Tønsberg - 8: on standing dead alder; 42: on mossy base of trunk of aspen tree. The specimens contain atranorin, zeorin and stictic acid complex.
LEPRARIA JACKII Tønsberg - 60: on trunk of larch. The specimen contains atranorin, roccellic/angardianic, jackinic/rangiformic and norjackinic/ norrangiformic acids.

LEPRARIA INCANA (L.) Ach. - 28-29, 59: on bases of trees, on mosses and stones. The specimens contain divaricatic acid, atranorin and zeorin.

LEPTOGIUM SATURNINUM (Dicks.) Nyl. -4: on standing dead aspen; 11, 28, 49: on bark of aspen; 20: on bark of willow; 49: on bark of bird-cherry tree.

LOBARIA PULMONARIA (L.) Hoffm. - 4: on standing dead aspen; 8, 22: on bark of aspen; 20: on bark of willow; 37-39, 41-44: on bark of aspen and willow. RR, RA.

LoXospora elatina (Ach.) A. Massal. - 6, 8, 16, $20,39,41-44,53$ : on bark and wood of trees of different species.

! Megaspora verrucosa (Ach.) Hafellner \& V. Wirth -21 : on bark of aspen. This is a common species reported from most regions of Russia (Urbanavichus, 2010). Previously known in Arkhangelsk Region only from its Arctic part (Lynge, 1928).

Melanelixia subaurifera (Nyl.) O. Blanco et al. 24: on bark and branches of aspen and birch; 53: on bark of bird-cherry tree.

!! Melanohalea exasperata (De Not.) O. Blanco et al. - 13: on treated wood and on bark of birch. This is a boreal species reported from most regions of Russia (Urbanavichus, 2010). Distribution in neighboring territories: the Republic of Karelia (Fadeeva et al., 2007), Komi Republic (Hermansson et al., 1998), Leningrad Region (Kuznetsova et al., 2007), and Murmansk Region (Urbanavichus et al., 2008). Species included in the Red Data Book of Murmansk Region (2014).

Melanohalea exasperatula (Nyl.) O. Blanco et al. -29 : on bark of rowan and willow.

Melanohalea olivacea (L.) O. Blanco et al. - 3-14, $16,20-22,24,27-29,32-34$ : on bark of deciduous and coniferous trees.

Micarea Elachista (Körb.) Coppins \& R. Sant. 25: on mossy stump.

Micarea melaena (Nyl.) Hedl. - 6: on bark of pine; 8-9: on burnt stumps; 34, 40: on bark of pine, spruce, deadwood and mosses. 
MicroCALICIUM AHLNERI Tibell - 12: on stump; 15: on treated wood.

Microcalicium arenarium (Hampe ex A. Massal.) Tibell - 12: on soil on roots of fallen dead spruce.

Microcalicium disseminatum (Ach.) Vain. - 12, 20: on bark of spruce; 16: on bark of larch; 43: on thalli of Loxospora elatina on bark of spruce.

Mycobilimbia CARNEOALBIDA (Müll. Arg.) S. Ekman \& Printzen - 4: on bark of standing dead aspen; 8: on bark of willow; $28,49,61$ : on mossy base on trunk of aspen.

MycoBILIMBIA EPIXANTHOIDEs (Nyl.) Vitik. et al. - 20, 22, 41: on mossy base of trunk of aspen.

Mycobilimbia TETRAmera (De Not.) Vitik. et al. ex Hafellner \& Türk - 22: on bark of aspen.

Mycoblastus AfFinis (Schaer.) T. Schauer - 59: on bark of old birch.

Mycoblastus SAnguinarius (L.) Norman - 3-10, $12,16,20-21,40,44,53$ : on bark of deciduous and coniferous trees and deadwood.

+Mycocalicium subtile (Pers.) Szatala - 13, 15, 49: on treated wood; 54: on bark of pines.

! Myriolecis CREnulata (Hook.) Śliwa et al. - 26: on concrete wall. This is a common species reported from most regions of Russia (Urbanavichus, 2010). Previously known in Arkhangelsk Region only from its Arctic part (Deichmann-Branth, 1885).

! Myriolecis dispersa (Pers.) Śliwa et al. - 26: on concrete wall. This is a common species reported from most regions of Russia (Urbanavichus, 2010). Previously known in Arkhangelsk Region only from its Arctic part (Blytt, 1872; Lynge, 1928).

MYRIOLECIS HAGENII (Ach.) Śliwa et al. -46-47: on bark of aspen and treated wood.

Myriolecis SAmbuci (Pers.) Clem. - 53: on bark of willow.

NAEtrocymbe Punctiformis (Pers.) R. C. Harris 22: on bark of aspen; 45: on bark of birch; 49: on bark of bird-cherry tree.

NePhroma BELlum (Spreng.) Tuck. - 20: on bark of willow; 22, 28, 63: on bark of aspen.

NePhroma PARILE (Ach.) Ach. - 1, 8, 28, 63: on bark of aspen.
NePhroma Resupinatum (L.) Ach. $-11,38$, 43: on bark of aspen; 20: on bark of willow.

OChrolechia AlBoflaVescens (Wulfen) Zahlbr. 53: on bark of pine, juniper and fallen dead pine.

OCHROLECHIA MAHLUENSIS Räsänen - 13, 66: on bark of birch; 14, 49, 63: on bark of alder; 15, 18, 58: on treated wood; 16: on bark of larch. The specimens contain gyrophoric and lecanoric acids.

OCHROLECHIA MiCROSTICTOIDES Räsänen - 10, 12: on bark of spruce; 16: on bark of larch.

Ochrolechia pallescens (L.) A. Massal. - 20: on bark of willow; 29: on bark of rowan, 63: on bark of aspen.

Palicella filamentosa (Stirt.) Rodr. Flakus \& Printzen - 5: on snag of pine.

PARMELIA SUlCATA Taylor - 1-44, 48-49, 54, 56, $60,62,67$ : on trunks, branches, decaying wood of different tree species, treated wood.

Parmeliopsis ambigua (Wulfen) Nyl. - 1- 44, 49$51,53-54,65$ : on trunks, branches, decaying wood of trees of different species, treated wood.

PARMELIOPSIS HYPEROPTA (Ach.) Arnold - 1-44, 51, 53,56 : on trunks and decaying wood of trees of different species, treated wood.

Peltigera aphthosa (L.) Willd. - 8: on mosses; 32: on soil, bases of trees.

Peltigera canina (L.) Willd. $-1,17$ : on soil; 42-43: on bases of old trees.

Peltigera didactyla (With.) J. R. Laundon - 17, 30, 56: on sandy soil.

!! Peltigera hymenina (Ach.) Delise - 2: on soil. This suboceanic species is reported from most regions of Russia (Urbanavichus at al., 2007). Distribution in neighboring territories: the Republic of Karelia (Fadeeva et al., 2007), Leningrad Region (Alexeeva, 2005), and Murmansk Region (Urbanavichus et al., 2008).

Peltigera malacea (Ach.) Funck - 55-56: on soil. Peltigera membranacea (Ach.) Nyl. - 56: on soil.

Peltigera Neckeri Hepp ex Müll. Arg. - 20: on bark of aspen and willow.

Peltigera neopolydactyla (Gyeln.) Gyeln. - 8: on mosses. 
Peltigera polydactylon (Neck.) Hoffm. - 33-34: on bark of aspen, mosses.

Peltigera praetextata (Flörke ex Sommerf.) Zopf-20, 49, 63: on bark of aspen; 30: on sandy soil; 65: on decaying tree.

Peltigera Rufescens (Weiss) Humb. - 30: on sandy soil.

Pertusaria Carneopallida (Nyl.) Anzi ex Nyl. - 49: on bark of alder.

PeRTUSARIA Leioplaca DC. - 22: on bark of aspen; 64: on bark of willow.

Phaeophyscia ciliata (Hoffm.) Moberg - 24: on bark of aspen.

!! Phatophyscia nigricans (Flörke) Moberg - 26: on concrete wall. This is a species reported from most regions of Russia (Urbanavichus, 2010). Distribution in neighboring territories: the Republic of Karelia (Fadeeva et al., 2007), Komi Republic (Hermansson et al., 1998), Leningrad Region (Kuznetsova et al., 2007), and Murmansk Region (Urbanavichus et al., 2008).

!! Phatophyscia orbicularis (Neck.) Moberg - 1: on bark of standing dead aspen; 26: on concrete wall. This is a boreal species reported from most regions of Russia (Urbanavichus, 2010). Distribution in neighboring territories: the Republic of Karelia (Fadeeva et al., 2007), Komi Republic (Hermansson et al., 1998), Leningrad Region (Kuznetsova et al., 2007), and Murmansk Region (Urbanavichus et al., 2008). Species included in the Red Data Book of Murmansk Region (2014).

Phaeophyscia Sciastra (Ach.) Moberg - 18: on treated wood and roofing paper; 25: on stones.

Phlyctis ARgena (Spreng.) Flot. - 1, 3-4, 6-8, $11-12,14,16,20-22,28-29,37-38,49$, 63: on bark of aspen and willow; 52: on bark of bird-cherry tree.

Physcia ADscendens H. Olivier - 1, 21, 24: on bark of aspen.

Physcia AIPOLIA (Ehrh. ex Humb.) Fürnr. - 24, 28: on bark of aspen.

PHYSCIA ALNOPHILA (Vain.) Loht. et al. - 29; on bark of rowan; 56: on bark of willow.

Physcia CAesia (Hoffm.) Fürnr. - 1: on bark of aspen; 18: on roofing paper; 26: on concrete wall.
Physcia STellaris (L.) Nyl. - 1, 21, 24: on bark of aspen.

Physcia tenella (Scop.) DC. - 26: on concrete wall; 29: on bark of rowan.

Physconia Distorta (With.) J. R. Laundon - 24; on bark of old aspen.

!! Placynthiella dasaea (Stirt.) Tønsberg - 43: on soil on root of fallen dead spruce. This is a boreal species reported from most regions of Russia (Urbanavichus, 2010). Distribution in neighboring territories: the Republic of Karelia (Fadeeva et al., 2007), Komi Republic (Hermansson et al., 1998), Leningrad Region (Kuznetsova et al., 2007), and Murmansk Region (Urbanavichus et al., 2008).

Placynthiella icmalea (Ach.) Coppins \& P. James $2,18,47,49,65,67$ : on treated wood; 5 : on snag of pine.

Platismatia glauca (L.) W. L. Culb. \& C. F. Culb. 1-44, 50, 52-54, 67: on trunks, branches, decaying wood of trees of different species, treated wood and stones.

Polycauliona CANDElaria (L.) Frödén et al. - 13, 17: on treated wood; 23, 46: on bark of pine and treated wood.

Polycauliona Polycarpa (Hoffm.) Frödén et al. 23: on bark of pine.

Porpidia CRUStUlata (Ach.) Hertel \& Knoph 35-36: on stones.

PorPidia MACROCARPa (DC.) Hertel \& A. J. Schwab 35-36: on stones.

Porpidia tUberculosa (Sm.) Hertel $\&$ Knoph - 15: on stones.

PROTOPARMELIOPSIS MURALIS (Schreb.) M. Choisy 25: on limestone.

PseudeVERnia FURfuracea (L.) Zopf -5 , 68: on branches of pine; 33, 44: on branches and trunks of pine, spruce, aspen. RA.

Pseudothelomma ocellatum (Körb.) M. Prieto \& Wedin -13, 17: on treated wood.

Psilolechia Lucida (Ach.) M. Choisy - 43: on soil on roots of fallen dead spruce.

PYCNORA SOROPHORA (Vain.) Hafellner - 10: on bark of pine. 
!! Pycnothelia Papillaria (Ehrh.) Dufour - 17: on sandy soil; 30: on wood. This is a species reported from most regions of Russia (Urbanavichus, 2010). Distribution in neighboring territories: the Republic of Karelia (Fadeeva et al., 2007), and Leningrad Region (Brenner, 1886). Species included in the Red Data Books of Leningrad Region (2000) and the Republic of Karelia (2020).

!! Ramalina Baltica Lettau - 21: on bark of willow. This is a species reported in Russia only from Northern part of European Russia (Urbanavichus, 2010). Previously known in Arkhangelsk Region only from Kozhozero Reserve (Fadeeva, 2006), but specimens have been redefined as Ramalina obtusata (by T. Ahti and V. Tarasova, in 2019). Distribution in neighboring territories: the Republic of Karelia (Fadeeva et al., 2007), and Leningrad Region (Kuznetsova et al., 2007).

RAMALINA FARINACEA (L.) Ach. - 14, 37: on bark of aspen; 20: on bark of spruce and willow.

RAMALINA POLLINARIA (Westr.) Ach. - 17: treated wood.

RAMALINA SINENSIS Jatta $-11,14,24$ : on bark of aspen.

Rhizocarpon badioatrum (Flörke ex Spreng.) Th. Fr. - 25: on stone.

RHIZOCARPON GEOGRAPHICUM (L.) DC. -25 , 36: on stones.

RHIZOCARPON GRANDE (Flörke) Arnold - 25, 36: on stones.

RHIZOCARPON HOCHSTETTERI (Körb.) Vain. - 25: on stones.

RINODINA ARCHAEA (Ach.) Arnold - 18: on treated wood; 49: on wood.

RINODINA SEPTENTRIONALIS Malme - 29: on bark of rowan; 56, 67: on bark of willow; 63: on bark of aspen.

ROPALOSPORA VIRIDIS (Tønsberg) Tønsberg - 49, 52: on trunk of bird-cherry tree. The specimens contain perlatolic acid.

Rostania Occultata (Bagl.) Otálora et al. - 20: on bark of willow; 21: on bark of aspen. RA(bs).

+SAREA DIFFORMIS (Fr.) Fr. - 44: on resin of spruce; 53: on bark of pines.

+SAREA REsinae (Fr.: Fr.) Kuntze - 27, 53: on resin of pine; 60: on bark of larch.
Scoliciosporum Chlorococcum (Graewe ex Stenh.) Vězda - 13: on branches of spruce; 15: on treated wood; 24: on bark of birch.

Scoliciosporum umbrinum (Ach.) Arnold - 58: on wood.

Scytinium teretiusculum (Wallr.) Otálora et al. 4: on bark of standing dead aspen; 22: on bark of aspen.

+Stenocybe pullatula (Ach.) Stein - 8: on bark of standing dead alder; 49: on bark of alder.

STEREOCAUlon PASCHALE (L.) Hoffm. - 27, 30: on soil.

Stereocaulon saXatile H. Magn. - 55: on stone.

STEREOCAULON TOMENTOSUM Fr. - 27, 30, 33: on soil.

STRANGOSPORA MORIFORMIS (Ach.) Stein - 13, 17: on treated wood.

TePHrOmela ATRA (Huds.) Hafellner - 36: on stone.

Toensbergia leucococca (R. Sant.) Bendiksby \& Timdal - 16: on branches of larch.

TONINIOPSIS SUBINCOMPTA (Nyl.) Kistenich et al. 1, 41: on bark of aspen; 4: on bark of standing dead aspen; 20: on bark of willow.

Trapeliopsis flexuosa (Fr.) Coppins \& P. James 2, 23: on treated wood.

TRAPELIOPSIS GRANUlosa (Hoffm.) Lumbsch - 33: on wood of spruce.

TucKermanNiopsis CHLOROPHYLla (Willd.) Hale 1-67: on trunks, branches, decaying wood of different tree species and treated wood.

USNEA DASOPOGA (Ach.) Nyl. - 8, 12, 66: on branches of spruce; 16: on bark of larch; 20: on bark of willow and branches of spruce; 51: on bark of pine; 59: on bark of old birch.

USNEA GLABRESCENS (Nyl. ex Vain.) Vain. ex Räsänen - 9: on bark of larch; 12, 48; on branches of spruce.

USNEA HIRTA (L.) Weber ex F.H.Wigg. - 13: on bark of birch; 17, 15: on treated wood; 20: on branches of spruce; 51 : on bark of pines.

USNEA PERPLEXANS Stirt. - 20: on branches of spruce.

USNEA SUbFloridana Stirt. - 1, 3-12, 16, 20-22, $29,32-34,50,53-54,60,62$ : on trunks and branches of trees of different species. 
Violella fucata (Stirt.) T. Sprib. - 5: on snag of pine; 16: on bark of spruce.

VulPiCIDA PINASTRI (Scop.) J.-E. Mattsson \& M. J. Lai - 1-44, 49, 54, 65: on trunks, branches, decaying wood of trees of different species, treated wood and stones.

XANTHORIA PARIETINA (L.) Th. Fr. - 1, 24: on bark of aspen.

Xylographa Pallens (Nyl.) Harm. - 2, 18: on treated wood.

Xylographa PaRallela (Ach.: Fr.) Fr. - 23, 46: on treated wood.

Xylographa trunciseda (Th. Fr.) Minks ex Redinger - 53: on wood.

XYLOGRAPHA VITILIGO (Ach.) J. R. Laundon - 20: on snags of spruce; 44, 53: on dead wood of pine.

!! Xylopsora Caradocensis (Nyl.) Bendiksby \& Timdal - 9: on burnt stump. Distribution in neighboring territories: the Republic of Karelia (Tarasova et al., 2013; Androsova et al., 2018), Komi Republic (Hermansson et al., 1998), Leningrad Region (Kuznetsova et al., 2007), and Murmansk Region (Urbanavichus et al., 2008).

XYLOPSORA FRIESII (Ach.) Bendiksby \& Timdal - 12: on stump; 33, 53: on deadwood of pine.

\section{ACKNOWLEDGEMENTS}

We would like to express our gratitude to the stuff of the Kenozersky National Park and Aleksander Kozykin for their help in organization of expedition to hard-to-reach areas. We are grateful to Elena Churakova, Viktor Juvanen and Matvei Juvanen for their assistance in the expedition work. The reported study was funded by RFBR (project number 20-04-00473). The work by Aleksey V. Pchelkin was carried out within the framework of the project "Lichenological survey of the territory of the Kenozersky National Park (Kargopol sector) and parts of the territory of the planned landscape reserve of regional significance "Lekshmokh", justification for granting the status of protected area" (2018). We are grateful to reviewers for valuable corrections and recommendations, which have improved the quality of our work.

\section{REFERENCES}

Alexeeva, N. 2005. Lichens from islands in the Russian part of the Gulf of Finland. Folia Cryptogamica Estonica 41: 5-12.

Androsova, V. I., Tarasova, V. N. \& Gorshkov, V. V. 2018. Diversity of lichens and allied fungi on Norway spruce (Picea abies) in the middle boreal forests of Republic of Karelia (Russia). Folia Cryptogamica Estonica 55: 133-149. https:/ / doi. org/ 10.12697 / fce.2018.55.14

Berteaux, D., Ricard, M., St-Laurent, M., Casajus, N., Perie, C., Beauregard, F. \& de Blois, Sylvie. 2018. Northern protected areas will become important refuges for biodiversity tracking suitable climates. Scientific Reports 8: 4623. https://doi. org/10.1038/s41598-018-23050-w

Blytt, A. 1872. Bidrag til Kundskaben om Vegetationen paa Nowaja Semlja, Waigatschoen og ved Jugorstraedet. Efter Samlinger hjembragte fra den Rosenthalske Expedition i 1871 ved Hr. Student Aagaard. Saerskilt aftrykt af Videnskabs-Selskabets Forhandlinger for 1872. P. 14-16.

Brenner, M. 1886. Bidrag till kännedom af Finska vikens övegetation. IV. Hoglands lafvar. Meddelanden af Societas pro Fauna et Flora Fennica 13: $1-143$.

Brzeziecki, B. 2017. Białowieża Forest as a biodiversity hotspot. Sylwan 161 (12): 671-981.

Byzova, N. M. 2016. Geographic image of the Kenozersky National Park. In: Proceedings of the VII International conference "Kenozero Readings 2015", "Reserved Kenozero: nature, culture, man" (in Russian). Arkhangelsk. Pp. 4-8.

Deichmann-Branth, I. S. 1885. Lichene fra NovaiaZemlia, samlede paa Dijmphna-Expeditionen 1882-83 af S. Borch og Th. Holm. DijmphnaTogtels zoologisk-botaniska Udbytte. Kobenhavn. Pp. 1-7.

Dymytrova, L., Nadyeina, O., Hobi, M. L. \& Scheidegger, C. 2014. Topographic and forest-stand variables determining epiphytic lichen diversity in the primeval beech forest in the Ukrainian Carpathians. Biodiversity and Conservation 23 (6): 1367-1394. DOI 10.1007/s10531-014-0670-1

Fadeeva, M. A. 2006. Lichens. In: Nature and historical and cultural heritage of Kozhozerye (in Russian). Arkhangelsk. Pp. 75-102.

Fadeeva, M. A., Golubkova, N. S., Vitikainen, O. \& Ahti, T. 2007. Conspectus of lichens and lichenicolous fungi of the Republic of Karelia (in Russian). Petrozavodsk. 194 pp.

Gray, C., Hill, S., Newbold, T., Lawrence, N., Hudson, L. N., Börger, L., Contu, S., Hoskins, A. J., Ferrier, S, Purvis, A. \& Scharlemann, J. P. W. 2016. Local biodiversity is higher inside than outside terrestrial protected areas worldwide. Nature Communications 7: 12306. https://doi.org/10.1038/ ncomms 12306

Halonen, P. 1993. The lichen flora of the Paanajärvi National Park. Oulanka Reports 12: 45-54. 
Handbook of lichens of Russia. 9. Fuscideaceae, Teloschistaceae (in Russian). 2004. St. Petersburg. $339 \mathrm{pp}$.

Hermansson, J., Pystina, N. T. \& Kudrejasheva, D. I. 1998. Previous list of lichens of the Republic of Komi (in Russian). Syktyvkar. 136 pp.

Hermansson, J., Tarasova, V. N., Stepanova, V. I. \& Sonina, A. V. 2002. Lichens of the Kivach Reserve (in Russian). Flora $i$ fauna zapovednikov 101: 1-35.

Hermansson, J.-O., Pystina, T. N., Ove-Larsson, B. \& Zhurbenko, M. P. 2006. Lichens and lichenophilic fungi of the Pechora-Ilych nature reserve (in Russian). Flora i fauna zapovednikov 109: 1-79.

Heuglin, W. Th. 1874. Kryptogame von Nowaja-Semlja und Waigatsch. Reisen nach dem Nordpolarmeer in den Jahren 1870 und 1871. 3 Theil. Beiträge für Fauna, Flora und Geologie. Braunschweig.

Kaluzkov, V. N. 2017. On the natural and toponymic heritage of Kenozero. In: Proceedings of the VIII International conference "Kenozero Readings 2016", "Wooden architecture in the cultural landscape: modern challenges" (in Russian). Arkhangelsk. Pp. 210-214.

Khastini R. O., Sari I. J., Herysca Y. \& Sulasanah S. 2019. Lichen diversity as indicators for monitoring ecosystem health in Rawa Danau Nature reserve, Banten, Indonesia. Biodiversitas 20 (2): 489-496. DOI 10.13057/biodiv/d200227

Kulikov, V. S., Kulikova V. V. \& Zudin A. I. 2015. The unique geographical "Point Maselga" in the Kenozersky National Park on the border of the natural countries of Fennoscandia and the Russian Plain as a modern educational facility. In: Proceedings of the IX International conference and summer school "Geology at school and university: geology and civilization”(in Russian). St. Petersburg. Pp. 345-350.

Kulikova, V. V. \& Kulikov, V. S. 2017. Geological sights and cultural heritage of the geological Kenozero ring "space" structure. In: Proceedings of the VIII International conference "Kenozero Readings - 2016", "Wooden architecture in the cultural landscape: modern challenges”(in Russian). Arkhangelsk. Pp. 215-224.

Kulikova, V. V., Kulikov, V. S., Bychkova, Ja. V. \& Melyutina, M. N. 2012. Kenozersky National Park area - a perspective unique geological object for environmental management. In: Proceedings of the III International conference "Environment and natural resource management" (in Russian). Tyumen. Pp. 122-124.

Kuznetsova, E., Ahti, T. \& Himelbrant, D. 2007. Lichens and allied fungi of the Eastern Leningrad Region. Norrlinia 16: 1-62.

Lynge, B. 1928. Lichens from Novaya Zemlya (exclusive of Acarospora and Lecanora). Report of the Scientific Result or the Norwegian Expedition to the Novaya Zemlya 1921 43: 1-299.

McMullin, R. T., Bennett, L. L., Bjorgan, O. J., Bourque, D. A., Burke, C. J., Clarke, M. A., Gutgesell,
M. K., Krawiec, P. L., Malyon, R., Mantione, A., Piotrowski, A. T., Tam, N. Y., van Natto, A. C., Wiersma, Y. F. \& Newmaster, S. G. 2016. Relationships between air pollution, population density, and lichen biodiversity in the Niagara Escarpment World Biosphere reserve. Lichenologist 48 (5): 593-605. DOI doi:10.1017/S0024282916000402

Nash, T. H. 2008. Lichen Biology. Cambridge University Press, Cambridge. 498 pp.

Nordin, A., Moberg, R., Tønsberg, T., Vitikainen, O., Dalsätt, Å., Myrdal, M., Snitting, D. \& Ekman, S. 2011. Santesson's Checklist of Fennoscandian Lichen-forming and Lichenicolous Fungi. Ver. April 29, 2011 - http://130.238.83.220/santesson/ home.php (25 January 2021).

Orange, A., James, P. W. \& White, F. J. 2001. Microchemical methods for the identification of lichens. British Lichen Society, London. 101 pp.

Palice, Z., Printzen, Ch., Spribille, T., Svensson, M., Tønsberg, T., Urbanavichene, I., Yakovchenko, L. S. \& Ekman, S. 2013. Taxonomy of the genus Myrionora, with a second species from the Southern Hemisphere. Lichenologist 45: 159-167. https://doi.org/10.1017/S0024282912000692

Pchelkin, A. V. 2019. Primary information about lichens of the Lekhmokh State Nature Reserve. (in Russian). Problems of environmental monitoring and ecosystem modeling 31 (3-4): 38-49.

Razumovskaja, A. V. 2018. Approaches to the compilation of a generalized large-scale vegetation map of the territory of the Kenozersky National Park. In: Geobotanical mapping (in Russian). St. Petersburg. Pp. 40-65.

Razumovskaja, A. V., Kucherov, I. B. \& Puchnina, L. V. 2012. Vascular plants of the Kenozersky National Park (annotated list of species) (in Russian). Arkhangelsk. 162 pp.

Red Data Book of Nature of the Leningrad Region (in Russian). 2000. St. Petersburg. 672 pp.

Red Data Book of the Arkhangelsk Region (in Russian). 2020. Arkhangelsk. 478 pp.

Red Data Book of the Murmansk Region (in Russian). 2014. Kemerovo. 584 pp.

Red Data Book of the Republic of Karelia (in Russian). 2020. Belgorod. 448 pp.

Red Data Book of the Russian Federation (plants and fungi) (in Russian). 2008. Moscow. 885 pp.

Stepanchikova, I. S., Kuznetsova, E. S. \& Himelbrant, D. E. 2009. New records of lichens and allied fungi from the Eastern Leningrad Region. Folia Cryptogamica Estonica 46: 75-78. https: / / ojs.utlib.ee/ index.php/FCE/article/view/ 13665

Tarasova, V. N., Androsova, V. I. \& Sonina, A. V. 2021. Lichens of the Vodlozersky National Park (Russia) (In Russian, English summary). Nature Conservation Research. Zapovednaya Nauka 6(1): 32-46. https://dx.doi.org/10.24189/ncr.2021.003

Tarasova, V. N., Obabko, R. P., Himelbrant, D. E., Boychuk, M. A., Stepanchikova, I. S. \& Borovichev, E. A. 2017. Diversity and distribution 
of epiphytic lichens and bryophytes on aspen (Populus tremula) in the middle boreal forests of Republic of Karelia (Russia). Folia Cryptogamica Estonica 54: 125-141. https://doi.org/10.12697/ fce. 2017.54 .16

Tarasova, V. N., Sonina, A. V., Androsova, V. I. \& Ahti, T. 2013. The present lichen flora of the city of Petrozavodsk. Folia Cryptogamica Estonica 50: 57-66. https://doi.org/10.12697/fce.2013.50.08

Tarasova, V. N., Sonina, A. V., Androsova, V. I. \& Stepanchikova, I. S. 2015. The lichens of forest rocky communities of mountain Olovgora (Arkhangelsk Region, Northwest Russia). Folia Cryptogamica Estonica 52: 51-62. http://dx.doi.org/10.12697/ fce.2015.52.07

Tarasova, V. N., Sonina, A. V., Androsova, V. I. \& Stepanchikova, I. S. 2016. The lichens of forest rocky communities of the hill Muroigora (Arkhangelsk Region, Northwest Russia). Folia Cryptogamica Estonica 53: 111-121. https://doi.org/10.12697/ fce.2016.53.13

Tarasova, V. N. \& Stepanchikova, I. S. 2016. New species of lichens for the Republic of Karelia. (in Russian). Scientific notes of Petrozavodsk State University, Biological sciences 4 (157): 78-82.

Torhov, S. V. 2012. Forests and forest management of the Kenozersky National Park. In: Proceedings of the V All-Russian conference "Kenozero Readings - 2011", "Man and Environment: Harmony and Contradictions" (in Russian). Severodvinsk. Pp. 227-232.
Urbanavichene, I. \& Urbanavichus, G. 2019. New records of lichens and allied fungi from the Kostroma Region, Russia. Folia Cryptogamica Estonica 56: 53-62. https://doi.org/10.12697/ fce.2019.56.06

Urbanavichus, G. P. 2010. A checklist of the lichen flora of Russia (in Russian). St. Petersburg. 194 pp.

Urbanavichus, G., Ahti, T. \& Urbanavichene I. 2008. Catalogue of lichens and allied fungi of Murmansk Region, Russia. Norrlinia 17: 1-80.

Urbanavichus, G. P. \& Fadeeva, M. A. 2018. Lichenoflora of the Pasvik reserve: diversity, distribution, ecology, protection (in Russian). Petrozavodsk: Karelian Scientific Center of the Russian Academy of Sciences. $173 \mathrm{pp}$.

Urbanavichus, G., Motiejûnaitë, J., Kukwa, M. \& Urbanavichene, I. 2007. Contribution to the biota of lichens and lichenicolous fungi of Murmansk region (NW Russia). Botanica Lithuanica 13(3): 197-202.

Waser, L.T., Kuechler, M., Schwarz, M., Ivits, E., Stofer, S. \& Scheidegger, C. 2007. Prediction of lichen diversity in an UNESCO biosphere reserve correlation of high resolution remote sensing data with field samples. Environmental Modeling and Assessment 12 (4): 315-328.

Zhang, J. L., Liu F. Z. \& Gui, G. F. 2016. Spatio-temporal variation of vegetation and analysis of its driving factors in Changbai Mountain National Nature reserve. Acta Ecologica Sinica 36 (12): 3525-3536. DOI:10.5846/stxb201410192053 
Appendix 1. Number of lichens and allied fungi in neighboring protected areas

\begin{tabular}{lllll}
\hline Protected area & Taiga subzone, region & $\begin{array}{l}\text { Area, } \\
\mathbf{k m}^{2}\end{array}$ & $\begin{array}{l}\text { Number of } \\
\text { species }\end{array}$ & References \\
\hline Kivach Nature Reserve & $\begin{array}{l}\text { middle boreal subzone, the } \\
\text { Republic of Karelia }\end{array}$ & 110 & 386 & $\begin{array}{l}\text { Hermansson et al., 2002; Tarasova } \\
\text { \& Stepanchikova, 2016; Tarasova et } \\
\text { al., 2017; Androsova et al., 2018 }\end{array}$ \\
\hline $\begin{array}{l}\text { Lekshmokh Nature } \\
\text { Reserve }\end{array}$ & $\begin{array}{l}\text { middle boreal subzone, } \\
\text { Arkhangelsk Region }\end{array}$ & 250 & 96 & Pchelkin, 2019 \\
\hline $\begin{array}{l}\text { Paanajarvi-Oulanka } \\
\text { National Park }\end{array}$ & $\begin{array}{l}\text { northern boreal subzone, the } \\
\text { Republic of Karelia, Finland }\end{array}$ & 1045 & 443 & Halonen, 1993 \\
\hline Pasvik Nature Reserve & $\begin{array}{l}\text { northern boreal subzone, } \\
\text { Murmansk Region }\end{array}$ & 147 & 587 & Urbanavichus \& Fadeeva, 2018 \\
\hline $\begin{array}{l}\text { Pechoro-Ilych Nature } \\
\text { Reserve }\end{array}$ & $\begin{array}{l}\text { northern and middle boreal } \\
\text { subzones, the Komi Republic }\end{array}$ & 7213 & 866 & Hermansson et al., 2006 \\
\hline $\begin{array}{l}\text { Vodlozersky National } \\
\text { Park }\end{array}$ & $\begin{array}{l}\text { northern and middle boreal } \\
\text { subzones, the Republic of } \\
\text { Karelia, Arkhangelsk Region }\end{array}$ & 4683 & 473 & Tarasova et al., 2021 \\
\hline
\end{tabular}


Appendix 2. List of sampling plots

\begin{tabular}{|c|c|c|c|c|c|}
\hline No. & Locality & Coordinates & Community & $\begin{array}{l}\text { Collector, } \\
\text { indetifier }\end{array}$ & Collection date \\
\hline 1 & $\begin{array}{l}\text { Morshichinskaya village, near } \\
\text { the church on the shore of } \\
\text { Lekshmozero Lake }\end{array}$ & $\begin{array}{l}63^{\circ} 45^{\prime} 58.9^{\prime \prime} \mathrm{N} \\
38^{\circ} 03^{\prime} 02.6^{\prime \prime} \mathrm{E}\end{array}$ & $\begin{array}{l}\text { individual spruce and aspen } \\
\text { trees }\end{array}$ & leg. \& det. VT & 11 July 2011 \\
\hline 2 & The Guzhevskaya Mill & $\begin{array}{l}61^{\circ} 49^{\prime} 29.3 ” \mathrm{~N} \\
37^{\circ} 56^{\prime} 20.5^{\prime \prime} \mathrm{E}\end{array}$ & wooden buildings & leg. \& det. VT & 11 July 2011 \\
\hline 3 & $-{ }_{-}$ & $\begin{array}{l}61^{\circ} 49^{\prime} 30.2^{\prime \prime} \mathrm{N}, \\
37^{\circ} 56^{\prime} 11.9^{\prime \prime} \mathrm{E} \\
\end{array}$ & $\begin{array}{l}\text { paludified peatmoss spruce } \\
\text { forest }\end{array}$ & leg. \& det. VT & 11 July 2011 \\
\hline 4 & - & $\begin{array}{l}61^{\circ} 49^{\prime} 33.8^{\prime \prime} \mathrm{N} \\
37^{\circ} 56^{\prime} 11.9^{\prime \prime} \mathrm{E}\end{array}$ & $\begin{array}{l}\text { horsetail peatmoss } \\
\text { spruce forest }\end{array}$ & leg. \& det. VT & 11 July 2011 \\
\hline 5 & $-{ }_{-}$ & $\begin{array}{l}61^{\circ} 49^{\prime} 36.4 ” \mathrm{~N} \\
37^{\circ} 56^{\prime} 12.2^{\prime \prime} \mathrm{E}\end{array}$ & $\begin{array}{l}\text { paludified peatmoss pine } \\
\text { forest }\end{array}$ & leg. \& det. VT & 11 July 2011 \\
\hline 6 & $-"$ & $\begin{array}{l}61^{\circ} 49^{\prime} 29.1^{\prime \prime} \mathrm{N} \\
37^{\circ} 56^{\prime} 12.9^{\prime \prime} \mathrm{E}\end{array}$ & $\begin{array}{l}\text { bilberry feathermoss spruce } \\
\text { forest }\end{array}$ & leg. \& det. VT & 11 July 2011 \\
\hline 7 & $\begin{array}{l}\text { The route from the Guzhevskaya } \\
\text { Mill to Bol'shoye Lebyazh'ye Lake }\end{array}$ & $\begin{array}{l}61^{\circ} 49^{\prime} 11.0 ” \mathrm{~N} \\
37^{\circ} 56^{\prime} 20.3^{\prime \prime} \mathrm{E}\end{array}$ & $\begin{array}{l}\text { paludified floodplain herb- } \\
\text { rich spruce forest }\end{array}$ & leg. \& det. VT & 12 July 2011 \\
\hline 8 & $-”$ & $\begin{array}{l}61^{\circ} 48^{\prime} 42.1^{\prime \prime} \mathrm{N} \\
37^{\circ} 55^{\prime} 46.4 ” \mathrm{E}\end{array}$ & $\begin{array}{l}\text { bilberry feathermoss spruce } \\
\text { forest }\end{array}$ & leg. \& det. VT & 12 July 2011 \\
\hline 9 &,- & $\begin{array}{l}61^{\circ} 48^{\prime} 32.3^{\prime \prime} \mathrm{N} \\
37^{\circ} 54^{\prime} 51.0^{\prime \prime} \mathrm{E}\end{array}$ & $\begin{array}{l}\text { bilberry feathermoss larch- } \\
\text { pine forest }\end{array}$ & leg. \& det. VT & 12 July 2011 \\
\hline 10 & $-{ }_{-}$ & $\begin{array}{l}61^{\circ} 48^{\prime} 28.1^{\prime \prime} \mathrm{N}, \\
37^{\circ} 54^{\prime} 01.1^{\prime \prime} \mathrm{E}\end{array}$ & $\begin{array}{l}\text { paludified peatmoss pine } \\
\text { forest }\end{array}$ & leg. \& det. VT & 12 July 2011 \\
\hline 11 &,- & $\begin{array}{l}61^{\circ} 48^{\prime} 19.8 ” \mathrm{~N} \\
37^{\circ} 54^{\prime} 07.8 ” \mathrm{E}\end{array}$ & $\begin{array}{l}\text { shore Bol'shoye Lebyazh'ye } \\
\text { Lake }\end{array}$ & leg. \& det. VT & 12 July 2011 \\
\hline 12 & -”- & $\begin{array}{l}61^{\circ} 49^{\prime} 09.8 ” \mathrm{~N} \\
37^{\circ} 55^{\prime} 38.6 ” \mathrm{E}\end{array}$ & $\begin{array}{l}\text { paludified peatmoss spruce } \\
\text { forest }\end{array}$ & leg. \& det. VT & 12 July 2011 \\
\hline 13 & Abandoned Guzhovo village & $\begin{array}{l}61^{\circ} 49^{\prime} 26.5^{\prime \prime} \mathrm{N}, \\
38^{\circ} 00^{\prime} 35.0^{\prime \prime} \mathrm{E} \\
\end{array}$ & wooden buildings & leg. \& det. VT & 13 July 2011 \\
\hline 14 & Near abandoned Guzhovo village & $\begin{array}{l}61^{\circ} 49^{\prime} 42.1^{\prime \prime} \mathrm{N}, \\
37^{\circ} 59^{\prime} 59.4^{\prime \prime} \mathrm{E}\end{array}$ & herb-rich alder-aspen forest & leg. \& det. VT & 13 July 2011 \\
\hline 15 & The church in Khizhgora & $\begin{array}{l}61^{\circ} 49^{\prime} 50.0 ” \mathrm{~N} \\
38^{\circ} 00^{\prime} 49.4 ” \mathrm{E} \\
\end{array}$ & wooden buildings & $\begin{array}{l}\text { leg. \& det. VT leg. } \\
\& \text { det. AP }\end{array}$ & $\begin{array}{l}3 \text { July } 2011 \\
8 \text { August } 2018 \\
\end{array}$ \\
\hline 16 & $\begin{array}{l}-0.8 \mathrm{~km} \text { to the east from the } \\
\text { Guzhevskaya Mill }\end{array}$ & $\begin{array}{l}61^{\circ} 49^{\prime} 26.1^{\prime \prime} \mathrm{N}, \\
37^{\circ} 57^{\prime} 17.8^{\prime \prime} \mathrm{E} \\
\end{array}$ & $\begin{array}{l}\text { bilberry feathermoss larch- } \\
\text { spruce-pine forest }\end{array}$ & leg. \& det. VT & 13 July 2011 \\
\hline 17 & $\begin{array}{l}\text { Novoselovo village on the SE shore } \\
\text { of Lekshmozero Lake }\end{array}$ & $\begin{array}{l}61^{\circ} 42^{\prime} 04.2^{\prime \prime} \mathrm{N} \\
38^{\circ} 10^{\prime} 15.6^{\prime \prime} \mathrm{E}\end{array}$ & wooden buildings & leg. \& det. VT & 14 July 2011 \\
\hline 18 & $\begin{array}{l}\text { Kazarinovskaja village on the SE } \\
\text { shore of Lekshmozero Lake }\end{array}$ & $\begin{array}{l}61^{\circ} 41^{\prime} 58.0^{\prime \prime} \mathrm{N} \\
38^{\circ} 10^{\prime} 15.5^{\prime \prime} \mathrm{E} \\
\end{array}$ & wooden buildings & leg. \& det. VT & 14 July 2011 \\
\hline 19 & $\begin{array}{l}-2.5 \mathrm{~km} \text { to the north from } \\
\text { Novoselovo village }\end{array}$ & $\begin{array}{l}61^{\circ} 43^{\prime} 03.5^{\prime \prime} \mathrm{N} \\
38^{\circ} 08^{\prime} 59.9^{\prime \prime} \mathrm{E}\end{array}$ & $\begin{array}{l}\text { bilberry feathermoss spruce } \\
\text { forest }\end{array}$ & leg. \& det. VT & 15 July 2011 \\
\hline 20 & $\begin{array}{l}-3 \mathrm{~km} \text { to the north from } \\
\text { Novoselovo village }\end{array}$ & $\begin{array}{l}61^{\circ} 43^{\prime} 52.8^{\prime \prime} \mathrm{N} \\
38^{\circ} 08^{\prime} 52.4^{\prime \prime} \mathrm{E}\end{array}$ & $\begin{array}{l}\text { paludified herb-rich spruce } \\
\text { forest }\end{array}$ & leg. \& det. VT & 15 July 2011 \\
\hline 21 & $\begin{array}{l}-2.5 \mathrm{~km} \text { to the north from } \\
\text { Novoselovo village }\end{array}$ & $\begin{array}{l}61^{\circ} 43^{\prime} 02.9^{\prime \prime} \mathrm{N} \\
38^{\circ} 08^{\prime} 58.6^{\prime \prime} \mathrm{E}\end{array}$ & herb-rich birch forest & leg. \& det. VT & 15 July 2011 \\
\hline 22 & $\begin{array}{l}\text { Southern shore of Lekshmozero } \\
\text { Lake }\end{array}$ & $\begin{array}{l}61^{\circ} 40 ’ 27.9 ” \mathrm{~N} \\
38^{\circ} 10^{\prime} 17.0 ” \mathrm{E}\end{array}$ & herb-rich aspen forest & leg. \& det. VT & 15 July 2011 \\
\hline 23 & $\begin{array}{l}\text { Morshichinskaya village, near the } \\
\text { pier and the visitor center }\end{array}$ & $\begin{array}{l}61^{\circ} 45^{\prime} 58.3^{\prime \prime} \mathrm{N} \\
38^{\circ} 03^{\prime} 17.7^{\prime \prime} \mathrm{E} \\
\end{array}$ & individual pine trees & leg. $\&$ det. $\mathrm{AP}$ & 6 August 2018 \\
\hline 24 & $\begin{array}{l}\text { The edge of the forest near the west } \\
\text { shore of Lekshmozero }\end{array}$ & $\begin{array}{l}61^{\circ} 45^{\prime} 59.4 ” \mathrm{~N} \\
38^{\circ} 03^{\prime} 32.7^{\prime \prime} \mathrm{E} \\
\end{array}$ & $\begin{array}{l}\text { herb-rich aspen forest with } \\
\text { birch }\end{array}$ & leg. \& det. AP & 6 August 2018 \\
\hline 25 & West shore of Lekshmozero Lake & $\begin{array}{l}61^{\circ} 42^{\prime} 13.6 ” \mathrm{~N} \\
38^{\circ} 03^{\prime} 46.7^{\prime \prime} \mathrm{E} \\
\end{array}$ & $\begin{array}{l}\text { individual boulders on the } \\
\text { shore }\end{array}$ & leg. \& det. AP & 7 August 2018 \\
\hline 26 & $\begin{array}{l}\text { North side of Morshichinskaya } \\
\text { village }\end{array}$ & $\begin{array}{l}61^{\circ} 46^{\prime} 29.7^{\prime \prime} \mathrm{N} \\
38^{\circ} 02^{\prime} 33.4^{\prime \prime} \mathrm{E} \\
\end{array}$ & old concrete slabs & leg. \& det. AP & 7 August 2018 \\
\hline
\end{tabular}




\begin{tabular}{|c|c|c|c|c|c|}
\hline No. & Locality & Coordinates & Community & $\begin{array}{l}\text { Collector, } \\
\text { indetifier }\end{array}$ & Collection date \\
\hline 27 & $\begin{array}{l}\text { Western slope near the road to } \\
\text { Morshichinskaya village }\end{array}$ & $\begin{array}{l}61^{\circ} 44^{\prime} 54.0 ” \mathrm{~N} \\
38^{\circ} 00^{\prime} 18.4 ” \mathrm{E}\end{array}$ & $\begin{array}{l}\text { bilberry lichen-feathermoss } \\
\text { spruce-pine forest }\end{array}$ & leg. \& det. AP & 7 August 2018 \\
\hline 28 & $\begin{array}{l}\text { The isthmus between Vilno Lake } \\
\text { and Maselskoe Lake }\end{array}$ & $\begin{array}{l}61^{\circ} 48^{\prime} 38.4^{\prime \prime} \mathrm{N} \\
38^{\circ} 03^{\prime} 39.2^{\prime \prime} \mathrm{E}\end{array}$ & herb-rich aspen forest & leg. \& det. AP & 8 August 2018 \\
\hline 29 & $\begin{array}{l}\text { Near the road from village of } \\
\text { Maselga to Khizhgora }\end{array}$ & $\begin{array}{l}61^{\circ} 49^{\prime} 52.2^{\prime \prime} \mathrm{N} \\
38^{\circ} 01^{\prime} 22.8^{\prime \prime} \mathrm{E} \\
\end{array}$ & $\begin{array}{l}\text { herb-rich spruce forest with } \\
\text { birch and alder }\end{array}$ & leg. \& det. AP & 8 August 2018 \\
\hline 30 & $\begin{array}{l}\text { Abandoned airfield }-1 \mathrm{~km} \text { to the } \\
\text { south of Ilekinskaya village }\end{array}$ & $\begin{array}{l}61^{\circ} 41^{\prime} 20.4 ” \mathrm{~N} \\
38^{\circ} 04^{\prime} 40.4 ” \mathrm{E}\end{array}$ & $\begin{array}{l}\text { moss and lichen cover on } \\
\text { sandy soil }\end{array}$ & leg. $\&$ det. $\mathrm{AP}$ & 9 August 2018 \\
\hline 31 & $\begin{array}{l}\text { Southern shore of Lekshmozero } \\
\text { Lake }\end{array}$ & $\begin{array}{l}61^{\circ} 40^{\prime} 45.0^{\prime \prime} \mathrm{N} \\
38^{\circ} 06^{\prime} 21.9^{\prime \prime} \mathrm{E} \\
\end{array}$ & bare soil & leg. \& det. AP & 9 August 2018 \\
\hline 32 & $\begin{array}{l}\text { The trail from Morshchinskaya } \\
\text { village to hay meadow }\end{array}$ & $\begin{array}{l}61^{\circ} 46 \prime 20.5^{\prime \prime} \mathrm{N} \\
38^{\circ} 0427.2^{\prime \prime} \mathrm{E} \\
\end{array}$ & $\begin{array}{l}\text { feathermoss-lichen pine } \\
\text { forest with birch }\end{array}$ & leg. \& det. AP & 9 August 2018 \\
\hline 33 & $\begin{array}{l}\text { The forest near the "Trail of } \\
\text { Anthills" }\end{array}$ & $\begin{array}{l}61^{\circ} 46^{\prime} 08.6^{\prime \prime} \mathrm{N} \\
38^{\circ} 04^{\prime} 02.2^{\prime \prime} \mathrm{E}\end{array}$ & $\begin{array}{l}\text { blueberry feathermoss birch- } \\
\text { spruce-pine forest }\end{array}$ & leg. $\&$ det. AP & 10 August 2018 \\
\hline 34 &,- & $\begin{array}{l}61^{\circ} 46^{\prime} 05.0^{\prime \prime} \mathrm{N} \\
38^{\circ} 03^{\prime} 26.1^{\prime \prime} \mathrm{E}\end{array}$ & $\begin{array}{l}\text { herb-rich pine forest with } \\
\text { birch }\end{array}$ & leg. \& det. AP & 10 August 2018 \\
\hline 35 & $\begin{array}{l}\text { The road along the route "Ancestral } \\
\text { Trail" }\end{array}$ & $\begin{array}{l}61^{\circ} 46^{\prime} 35.0^{\prime \prime} \mathrm{N} \\
38^{\circ} 01^{\prime} 58.3 ” \mathrm{E} \\
\end{array}$ & isolated stones on the road & leg. $\&$ det. AP & 10 August 2018 \\
\hline 36 & The Nikolin Stone & $\begin{array}{l}61^{\circ} 46^{\prime} 34.8^{\prime \prime} \mathrm{N} \\
38^{\circ} 01^{\prime} 48.6 ” \mathrm{E}\end{array}$ & isolated big stone & leg. \& det. AP & 11 August 2018 \\
\hline 37 & -”- & $\begin{array}{l}61^{\circ} 46^{\prime} 59.9^{\prime \prime} \mathrm{N} \\
38^{\circ} 00^{\prime} 33.4 ” \mathrm{E}\end{array}$ & $\begin{array}{l}\text { herb-rich aspen forest with } \\
\text { birch and spruce }\end{array}$ & leg. $\&$ det. AP & 11 August 2018 \\
\hline 38 & $-{ }_{-}$ & $\begin{array}{l}61^{\circ} 47^{\prime} 04.7 ” \mathrm{~N} \\
38^{\circ} 00^{\prime} 06.7^{\prime \prime} \mathrm{E}\end{array}$ & $\begin{array}{l}\text { herb-rich aspen forest with } \\
\text { birch and spruce }\end{array}$ & leg. \& det. AP & 11 August 2018 \\
\hline 39 & -”- & $\begin{array}{l}61^{\circ} 47^{\prime} 04.7^{\prime \prime} \mathrm{N} \\
37^{\circ} 59^{\prime} 20.3 ” \mathrm{E} \\
\end{array}$ & $\begin{array}{l}\text { herb-rich aspen forest with } \\
\text { birch and spruce }\end{array}$ & leg. \& det. AP & 11 August 2018 \\
\hline 40 & -”- & $\begin{array}{l}61^{\circ} 47^{\prime} 10.2 ” \mathrm{~N} \\
37^{\circ} 58^{\prime} 33.7^{\prime \prime} \mathrm{E} \\
\end{array}$ & $\begin{array}{l}\text { herb-rich pine forest with } \\
\text { birch and spruce }\end{array}$ & leg. \& det. AP & 11 August 2018 \\
\hline 41 & $\begin{array}{l}-1 \mathrm{~km} \text { to the south from } \\
\text { Ivshinskaya village }\end{array}$ & $\begin{array}{l}61^{\circ} 41^{\prime} 13.3 ” \mathrm{~N} \\
38^{\circ} 11^{\prime} 25.11^{\prime \prime} \mathrm{E} \\
\end{array}$ & $\begin{array}{l}\text { herb-rich aspen forest with } \\
\text { birch and spruce }\end{array}$ & leg. \& det. AP & 13 August 2018 \\
\hline 42 & $\begin{array}{l}-1,5 \mathrm{~km} \text { to the south from } \\
\text { Ivshinskaya village }\end{array}$ & $\begin{array}{l}61^{\circ} 41^{\prime} 06.9 ” \mathrm{~N} \\
38^{\circ} 12^{\prime} 17.8^{\prime \prime} \mathrm{E} \\
\end{array}$ & $\begin{array}{l}\text { herb-rich aspen forest with } \\
\text { birch and spruce }\end{array}$ & leg. \& det. AP & 14 August 2018 \\
\hline 43 & $\begin{array}{l}-2 \mathrm{~km} \text { to the south-east from } \\
\text { Ivshinskaya village }\end{array}$ & $\begin{array}{l}61^{\circ} 40^{\prime} 56.9 ” \mathrm{~N} \\
38^{\circ} 12^{\prime} 47.5^{\prime \prime} \mathrm{E} \\
\end{array}$ & $\begin{array}{l}\text { herb-rich aspen forest with } \\
\text { birch and spruce }\end{array}$ & leg. $\&$ det. AP & 14 August 2018 \\
\hline 44 & $\begin{array}{l}6 \mathrm{~km} \text { to the south-east from } \\
\text { Ivshinskaya village }\end{array}$ & $\begin{array}{l}61^{\circ} 40^{\prime} 50.0 ” \mathrm{~N} \\
38^{\circ} 13^{\prime} 58.4 ” \mathrm{E} \\
\end{array}$ & $\begin{array}{l}\text { swampy spruce forest with } \\
\text { birch }\end{array}$ & leg. \& det. AP & 15 August 2018 \\
\hline 45 & Near Ivshinskaya village & $\begin{array}{l}61^{\circ} 41^{\prime} 37.3 ” \mathrm{~N} \\
38^{\circ} 10^{\prime} 41.9 ” \mathrm{E} \\
\end{array}$ & wood of standing dead birch & leg. $\&$ det. AP & 15 August 2018 \\
\hline 46 & $\begin{array}{l}\text { Old barns on the shore of } \\
\text { Lekshmozero Lake }\end{array}$ & $\begin{array}{l}61^{\circ} 45^{\prime} 57.2^{\prime \prime} \mathrm{N} \\
38^{\circ} 03^{\prime} 06.8^{\prime \prime} \mathrm{E} \\
\end{array}$ & on treated wood & leg. \& det. AP & 15 August 2018 \\
\hline 47 & $\begin{array}{l}\text { The roof of abandoned house in } \\
\text { Ivshinskaya village }\end{array}$ & $\begin{array}{l}61^{\circ} 41^{\prime} 40.0^{\prime \prime} \mathrm{N} \\
38^{\circ} 10^{\prime} 31.4 ” \mathrm{E} \\
\end{array}$ & on treated wood & leg. \& det. AP & 15 August 2018 \\
\hline 48 & $\begin{array}{l}\text { The road from the Porzhensky } \\
\text { churchyard to Vidyagino village }\end{array}$ & $\begin{array}{l}61^{\circ} 56^{\prime} 43.78^{\prime \prime} \mathrm{N}, \\
38^{\circ} 7^{\prime} 32.76^{\prime \prime} \mathrm{E} \\
\end{array}$ & $\begin{array}{l}\text { bilberry feathermoss aspen- } \\
\text { pine-spruce forest }\end{array}$ & leg. AV, det. VT & 22 May 2019 \\
\hline 49 & $\begin{array}{l}\text { Hilly plain between Maloe } \\
\text { Porzhensky Lake and Saremoh mire }\end{array}$ & $\begin{array}{l}61^{\circ} 54^{\prime} 8.53^{\prime \prime} \mathrm{N} \\
38^{\circ} 8^{\prime} 1.81^{\prime \prime} \mathrm{E}\end{array}$ & $\begin{array}{l}\text { bilberry feathermoss spruce- } \\
\text { birch-aspen forest }\end{array}$ & leg. AV, det. VT & 24 May 2019 \\
\hline 50 & Near the Saremoh mire & $\begin{array}{l}61^{\circ} 53^{\prime} 34.48^{\prime \prime} \mathrm{N}, \\
38^{\circ} 9^{\prime} 12.40^{\prime \prime} \mathrm{E}\end{array}$ & $\begin{array}{l}\text { bilberry feathermoss birch- } \\
\text { aspen forest }\end{array}$ & leg. AV, det. VT & 24 May 2019 \\
\hline 51 & The Saremoh mire & $\begin{array}{l}61^{\circ} 53^{\prime} 33.13^{\prime \prime} \mathrm{N}, \\
38^{\circ} 9^{\prime} 17.89^{\prime \prime} \mathrm{E} \\
\end{array}$ & $\begin{array}{l}\text { padutified peatmoss pine } \\
\text { forest }\end{array}$ & leg. AV, det. VT & 24 May 2019 \\
\hline 52 & Floodplain of the Vilenka River & $\begin{array}{l}61^{\circ} 53^{\prime} 25.50^{\prime \prime} \mathrm{N} \\
38^{\circ} 6^{\prime} 4.17^{\prime \prime} \mathrm{E}\end{array}$ & $\begin{array}{l}\text { herb-rich willow-bird-cherry } \\
\text { forest }\end{array}$ & leg. AV, det. VT & 25 May 2019 \\
\hline 53 & Surroundings of Zheldozero Lake & $\begin{array}{l}61^{\circ} 53^{\prime} 22.32^{\prime \prime} \mathrm{N} \\
37^{\circ} 56^{\prime} 32.24^{\prime \prime} \mathrm{E} \\
\end{array}$ & $\begin{array}{l}\text { cowberry feathermoss pine } \\
\text { forest }\end{array}$ & leg. AV, det. VT & 26 May 2019 \\
\hline
\end{tabular}




\begin{tabular}{|c|c|c|c|c|c|}
\hline No. & Locality & Coordinates & Community & $\begin{array}{l}\text { Collector, } \\
\text { indetifier }\end{array}$ & Collection date \\
\hline 54 & $\begin{array}{l}\text { The slope to the shore of Novgozero } \\
\text { Lake }\end{array}$ & $\begin{array}{l}61^{\circ} 53^{\prime} 6.27^{\prime \prime} \mathrm{N} \\
37^{\circ} 59^{\prime} 6.49^{\prime \prime} \mathrm{E}\end{array}$ & herb-rich aspen-spruce forest & leg. AV, det. VT & 26 May 2019 \\
\hline 55 & Steep slope to Maselgskoe Lake & $\begin{array}{l}61^{\circ} 49^{\prime} 50.72^{\prime \prime} \mathrm{N}, \\
38^{\circ} 0 \text { '28.01”E }\end{array}$ & $\begin{array}{l}\text { heatherry feathermoss-lichen } \\
\text { pine forest }\end{array}$ & leg. AV, det. VT & 27 May 2019 \\
\hline 56 & $\begin{array}{l}\text { The foot of a large ridge near } \\
\text { Khizhgora }\end{array}$ & $\begin{array}{l}61^{\circ} 49^{\prime} 51.03^{\prime \prime} \mathrm{N}, \\
38^{\circ} 027.82^{\prime \prime} \mathrm{E}\end{array}$ & bare sandy soil & leg. AV, det. VT & 27 May 2019 \\
\hline 57 & The bank of the Cholma River & $\begin{array}{l}\text { 6139'54.10”N, } \\
38^{\circ} 11^{\prime} 26.67^{\prime \prime} \mathrm{E}\end{array}$ & $\begin{array}{l}\text { bilberry feathermoss pine } \\
\text { forest }\end{array}$ & leg. AV, det. VT & 28 May 2019 \\
\hline 58 & The bridge over the Cholma River & $\begin{array}{l}\text { 61\%40'14.30”N, } \\
38^{\circ} 11^{\prime} 8.79^{\prime \prime} \mathrm{E} \\
\end{array}$ & sedge thickets & leg. AV, det. VT & 28 May 2019 \\
\hline 59 & Western shore of Naglimozero Lake & $\begin{array}{l}61^{\circ} 46^{\prime} 15.73^{\prime \prime} \mathrm{N}, \\
38^{\circ} 11^{\prime} 8.79^{\prime \prime} \mathrm{E} \\
\end{array}$ & $\begin{array}{l}\text { bilberry feathermoss aspen- } \\
\text { spruce forest }\end{array}$ & leg. AV, det. VT & 29 May 2019 \\
\hline 60 & Monastyrsky Island & $\begin{array}{l}61^{\circ} 46^{\prime} 38.30^{\prime \prime} \mathrm{N}, \\
37^{\circ} 57^{\prime} 0.44 ” \mathrm{E}\end{array}$ & $\begin{array}{l}\text { bilberry feathermoss aspen- } \\
\text { spruce-larch forest }\end{array}$ & leg. AV, det. VT & 29 May 2019 \\
\hline 61 & Creek valley near Naglimozero Lake & $\begin{array}{l}61^{\circ} 4613.59 ” \mathrm{~N}, \\
37^{\circ} 55^{\prime} 36.93^{\prime \prime} \mathrm{E}\end{array}$ & $\begin{array}{l}\text { paludified herb-rich aspen } \\
\text { forest }\end{array}$ & leg. AV, det. VT & 29 May 2019 \\
\hline 62 & West bank of Naglimozero Lake & $\begin{array}{l}61^{\circ} 46^{\prime} 15.36 ” \mathrm{~N} \\
37^{\circ} 55^{\prime} 40.87^{\prime \prime} \mathrm{E}\end{array}$ & $\begin{array}{l}\text { bilberry feathermoss spruce- } \\
\text { pine forest }\end{array}$ & leg. AV, det. VT & 29 May 2019 \\
\hline 63 & Naglimozero Lake shore & $\begin{array}{l}61^{\circ} 46^{\prime} 18.49^{\prime \prime} \mathrm{N}, \\
37^{\circ} 55^{\prime} 41.866^{\prime \prime} \mathrm{E}\end{array}$ & herb-rich aspen-spruce forest & leg. AV, det. VT & 29 May 2019 \\
\hline 64 & Creek valley near Naglimozero Lake & $\begin{array}{l}61^{\circ} 46^{\prime} 12.98^{\prime \prime} \mathrm{N} \\
37^{\circ} 55^{\prime} 40.88^{\prime \prime} \mathrm{E}\end{array}$ & $\begin{array}{l}\text { paludifield nerb-rich willow } \\
\text { forest }\end{array}$ & leg. AV, det. VT & 29 May 2019 \\
\hline 65 & Kaskozero Lake shore & $\begin{array}{l}61^{\circ} 40^{\prime} 44.51^{\prime \prime} \mathrm{N}, \\
38^{\circ} 2^{\prime} 42.31^{\prime \prime} \mathrm{E}\end{array}$ & $\begin{array}{l}\text { paludified floodplain herb- } \\
\text { rich birch-spruce forest }\end{array}$ & leg. AV, det. VT & 29 May 2019 \\
\hline 66 & The Kulgom brook & $\begin{array}{l}61^{\circ} 49^{\prime} 28.66^{\prime \prime} \mathrm{N}, \\
37^{\circ} 56^{\prime} 20.96 ” \mathrm{E}\end{array}$ & $\begin{array}{l}\text { paludified floodplain herb- } \\
\text { rich willow-birch forest }\end{array}$ & leg. AV, det. VT & 31 May 2019 \\
\hline 67 & Near the Water Mill & $\begin{array}{l}61^{\circ} 49^{\prime} 27.46 ” \mathrm{~N}, \\
37^{\circ} 56^{\prime} 25.63 ” \mathrm{E} \\
\end{array}$ & tourist parking area & leg. AV, det. VT & 31 May 2019 \\
\hline 68 & Near the Lekshmokh nature reserve & $\begin{array}{l}61^{\circ} 40^{\prime} 49.4 » \mathrm{~N} \\
38^{\circ} 14^{\prime} 01.7 » \mathrm{E}\end{array}$ & $\begin{array}{l}\text { paludified peatmoss pine } \\
\text { forest }\end{array}$ & leg. \& det. AP & 15 August 2018 \\
\hline
\end{tabular}

Notes. The names of the collectors are abbreviated as follows: AP - Alexey Pchelkin, AV - Andrei Valekzhanin, VT - Viktoria Tarasova. 